\title{
Rapportage ontwikkeling protocol voor uniforme beoordeling essentaksterfte
}

Projectgroep:

A.J. van Kuik ${ }^{1}$, J.A. Hiemstra ${ }^{1}$, J. Kopinga ${ }^{2}$, H. Kuppen ${ }^{3}$ en R. Schraven ${ }^{4}$.

1: Wageningen University \& Research

2: Kopinga Boomadvies

3: Terra Nostra

4: BTL Bomendienst

WR is een onderdeel van Wageningen University \& Research, samenwerkingsverband tussen Wageningen University en de Stichting Wageningen Research. 
A.J. van Kuik et al. 2018. Rapportage ontwikkeling protocol voor uniforme beoordeling essentaksterfte. Wageningen Research, Rapport WPR-2018-06

Dit rapport is gratis te downloaden op https://doi.org/10.18174/454600

Trefwoorden: essentaksterfte, Hymenoscyphus fraxineus, protocol, boomveiligheidscontrole

(c) 2018 Wageningen, Stichting Wageningen Research, Wageningen Plant Research, Business unit Open Teelten, Postbus 200, 6670 AE Zetten; T 03174737 02; www.wur.nl/plant-research KvK: 09098104 te Arnhem

VAT NL no. 8113.83.696.B07

Stichting Wageningen Research. Alle rechten voorbehouden. Niets uit deze uitgave mag worden verveelvoudigd, opgeslagen in een geautomatiseerd gegevensbestand, of openbaar gemaakt, in enige vorm of op enige wijze, hetzij elektronisch, mechanisch, door fotokopieën, opnamen of enige andere manier zonder voorafgaande schriftelijke toestemming van Stichting Wageningen Research.

Stichting Wageningen Research is niet aansprakelijk voor eventuele schadelijke gevolgen die kunnen ontstaan bij gebruik van gegevens uit deze uitgave.

Rapport WPR-2018-06

Opdrachtgevers: VHG Platform Boomspecialisten en ISB in samenwerking met Stadwerk inzake Oogstfonds Bomenonderzoek.
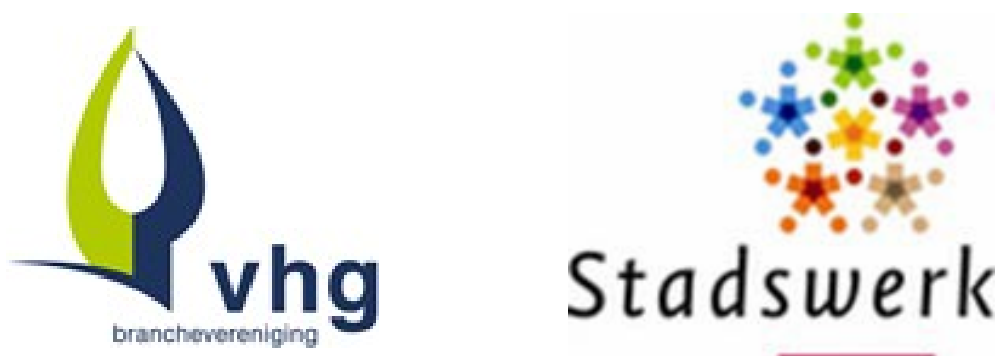

Projectdeelnemers: Terra Nostra, BTL Bomendienst en Kopinga Boomadvies.
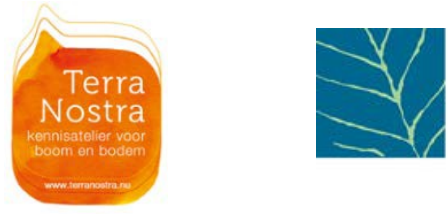

\section{BTL}

\section{Bomendienst}

Dit rapport is mede tot stand gekomen door bijdragen vanuit de klankbordgroep:

Herman Wevers, Carlo Kok, Lutein Rademaker, Gabriël Wevers, Alles over Groenbeheer

Harold Schoenmakers, ANDE(R)S Boomtechnisch Advies

Erik Koppelaar, Bomenwacht Nederland

Marc Custers, Branchevereniging VHG

J oost Verhagen, Cobra

Rudy Scheper, gemeente Dordrecht

Henk Langeveld, Edwin Arends, gemeente Groningen

Djorn Noordman, gemeente Haarlem

Dennis de Goederen, Pius Floris Boomverzorging

J os van der Vondervoort, Ronald Loch, gemeente Rotterdam

Roel Geerts, Remke Vos, Terra Nostra

Bernard Flier, Tree-o-logic

Rob Vermeulen, gemeente Utrecht

Bron van de foto's die in dit protocol voorkomen: Henry Kuppen, Terra Nostra 


\section{Inhoudsopgave}

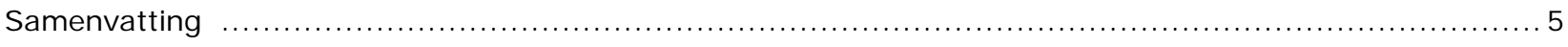

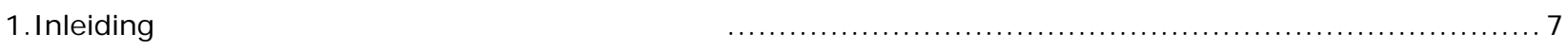

2.Doel

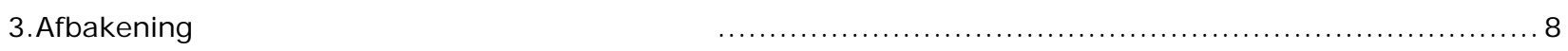

4.Aanpak en werkwijze

5. Resultaten

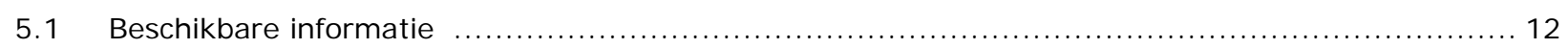

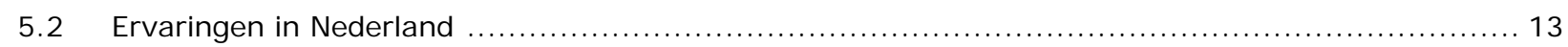

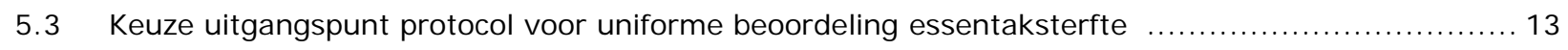

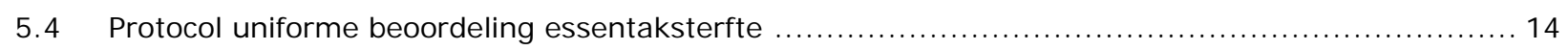

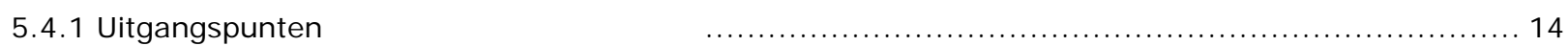

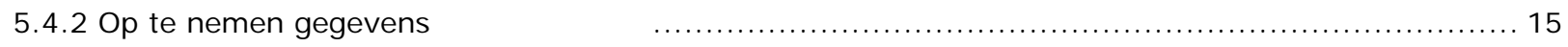

6. Literatuur

Bijlage 1 Ziektecyclus

Bijlage 2 Protocol voor uniforme beoordeling van essentaksterfte ...................................... 19 



\section{Samenvatting}

In opdracht van VHG Platform Boomspecialisten en de Intergemeentelijke Studiegroep Bomen (ISB) is een protocol gemaakt voor een uniforme opname van essentaksterfte (ETS) in stedelijke en landelijke omgevingen. In de praktijk bestaat bij de groenbeheerders, maar ook aannemers en adviseurs grote behoefte aan uniforme richtlijnen voor het beoordelen van ETS als basis voor huidige en toekomstige beheer- en beleidsplannen voor de es. Dit protocol kan worden gecombineerd met de reguliere visuele inspectie mits die in de voor het beoordelen van ETS juiste periode (juni t/m augustus) plaatsvindt en de waarnemer goed is geïnstrueerd in het gebruik van het ETS protocol.

In dit document zijn ten behoeve van de gebruikers door Wageningen University \& Research (WUR), Terra Nostra, BTL Bomendienst en Kopinga Boomadvies de beschikbare wetenschappelijke informatie én praktijkkennis gekoppeld met als resultaat een protocol voor uniforme beoordeling van ETS. Hiermee wordt het nu mogelijk om alle verzamelde data met betrekking tot het beoordelen van ETS te vergelijken en te analyseren. Hiermee krijgen we een completer en betrouwbaarder beeld van de ernst en de ontwikkeling van ETS in heel Nederland.

Het protocol bestaat uit een lijst van 22 op te nemen gegevens van de te beoordelen essen. De mate van aantasting wordt beoordeeld door het deel van de kroon waar het blad ontbreekt, op plaatsen waar het wel aanwezig zou moeten zijn, in te schatten. Tevens wordt ingeschat in welke mate de boom zijn bladoppervlakte tracht te herstellen door waterlotvorming. Hiermee kan de mate van aantasting van essen door ETS van zowel individuele bomen als van een populatie essen worden gevolgd en vergeleken.

Voor het monitoren van ETS in de loop van de tijd is het belangrijk om het type omgeving en het type groeiplaats eveneens vast te leggen. Hiermee kunnen mogelijke invloeden van omgevingsfactoren op het optreden van ETS worden geanalyseerd. Voor groenbeheerders is het gevaar dat kan ontstaan door afbrekende en uitvallende takken een serieus aandachtspunt. Daarom wordt met dit protocol ook geregistreerd of er afgestorven takken (dikker dan $4 \mathrm{~cm}$ en langer dan 1 meter) aanwezig zijn. Bij meerjarige monitoring kan dit ook inzicht geven in de snelheid waarmee (zwaar) dood hout wordt gevormd.

Het protocol beschrijft een standaardwijze voor het waarnemen en vastleggen van de belangrijkste aspecten die bij elke opname nodig zijn om onderlinge vergelijking van de resultaten mogelijk te maken. Daarnaast kan elke opdrachtgever of uitvoerende partij dit verder uitbreiden met andere voor hem of haar van belang zijnde aspecten. Dit protocol maakt het mogelijk om onderbouwde boombeheeradviezen te geven voor Fraxinus-soorten in relatie tot ETS.

NB. Het protocol beperkt zich tot ETS en is niet ontwikkeld voor andere ziekten of aantastingen. Verder maakt de grote variatie van uitingsvormen van ETS in de praktijk het nodig dat de waarnemer is 'geschoold' in het herkennen van ETS en het werken met dit protocol. 



\section{Inleiding}

Essentaksterfte (hierna ETS) veroorzaakt door de schimmel Hymenoscyphus fraxineus (originele naam: Chalara fraxinea) is een relatief nieuwe boomziekte die vanaf medio jaren ' 90 in Oost-Europa en vanaf ongeveer 2010 ook in Nederland in toenemende mate leidt tot sterfte van essen (Fraxinus). De gewone es (Fraxinus excelsior), een veelgebruikte en daarmee belangrijke laan- en straatboomsoort in Nederland, zowel in het buitengebied als in de stad, blijkt zeer gevoelig voor ETS. Gemeenten bezitten na Staatsbosbeheer (SBB) het grootste aantal essen. De schade in bosgebieden is inmiddels zeer groot. Bomen in de stedelijke en landelijke omgeving lijken minder vaak en/of minder zwaar aangetast te worden dan bomen in gesloten beplantingen, zoals bomen in bosverbanden en in essenhakhoutopstanden. In de stedelijke en landelijke omgeving komen ook andere Fraxinus soorten en cultivars van F. excelsior voor die in een aantal gevallen minder last lijken te hebben van ETS, maar een compleet beeld hiervan ontbreekt nog. Verder is het microklimaat rond deze straatbomen niet vergelijkbaar met dat van een bosomgeving. Door deze verschillen is het verloop van de ziekte in es, als straatboom geplant, moeilijk in te schatten en de impact (nog) niet met zekerheid aan te geven.

Om een goede risico-inschatting te kunnen maken van de impact van ETS in de stedelijke omgeving zijn veel waarnemingsgegevens nodig. Tot op heden gebruiken de meeste gemeenten een vorm van visuele inspectie om de boomveiligheid en -gezondheid te beoordelen. De inspecties worden onder andere uitgevoerd door personen met toepasselijke certificaten van Stichting Groenkeur zoals Boom Veiligheidscontroleur (BVC). Binnen de visuele inspectie worden gebreken aan bomen geregistreerd. Specifieke data met betrekking tot ETS vallen hier niet onder, waardoor veel vragen rond de ernst van ETS en noodzaak tot het treffen van beheermaatregelen onbeantwoord blijven.

Meerdere boomtechnische adviesbedrijven houden zich al enige tijd bezig met het systematisch beoordelen en registreren van essen in verschillende stedelijke en landelijke omgevingen. Voor het beoordelen van ETS waren tot op heden echter nog geen uniforme richtlijnen. In de praktijk worden verschillende protocollen gebruikt, met onderling soms substantiële verschillen. De verzamelde data zijn hierdoor niet uitwisselbaar en ook niet goed te vergelijken, dan wel wetenschappelijk te analyseren. Er is daarmee ook nog geen volledig beeld van de ernst van ETS in heel Nederland.

In de praktijk bestaat daarom zowel bij de groenbeheerders als de uitvoerders van de inspecties als onderzoekers betrokken bij ETS grote behoefte aan uniforme richtlijnen voor het beoordelen van ETS als basis voor huidige en toekomstige beheer- en beleidsplannen van de es. Daarom is in 2018 door VHG Platform Boomspecialisten en de Intergemeentelijke Studiegroep Bomen (ISB) een project geïnitieerd om te komen tot een protocol voor een uniforme opname van ETS. Aan Wageningen University \& Research (WUR) is gevraagd om op basis van de beschikbare wetenschappelijke informatie én praktijkkennis ingebracht door Terra Nostra, BTL Bomendienst en Kopinga Boomadvies een protocol voor uniforme beoordeling van ETS op te stellen.

Dit protocol kan worden gecombineerd met de reguliere visuele (boom-) inspectie mits die in de voor het beoordelen van ETS juiste periode (juni $\mathrm{t} / \mathrm{m}$ augustus) plaatsvindt en de waarnemer goed is geïnstrueerd in het gebruik van het ETS protocol. 


\section{Doel}

Op basis van de huidige kennis en reeds beschikbare (werk)handleidingen voor ETS wordt een protocol voor opname van ETS gemaakt, dat wetenschappelijk is onderbouwd (eenduidig en controleerbaar) en wordt gedragen door de praktijk. Dit protocol is landelijk toepasbaar voor het in het veld vastleggen van ETS-aantasting in stedelijke en landelijke beplanting.

Het doel is het verkrijgen van een eenduidig, controleerbaar en uitwisselbaar protocol voor opname en vastleggen van gegevens betreffende ETS.

\section{Afbakening}

In dit project wordt een landelijk protocol ontwikkeld voor het uniform beoordelen van de mate van aantasting van de es door ETS in de stedelijke omgeving. Dat wil zeggen, een protocol dat kan worden gebruikt voor het beoordelen van ETS in stadsbomen en essen in beplantingen langs wegen (straat- en laanbomen). Het protocol beperkt zich tot ETS en is niet ontwikkeld voor andere ziekten en/ of aantastingen.

Het protocol is bedoeld om te komen tot uniformiteit in de opname en monitoring van ETS zodat opnamegegevens van verschillende gebieden in de toekomst onderling vergelijkbaar worden. Het protocol beschrijft een standaardwijze voor het waarnemen en vastleggen van de belangrijkste aspecten die bij elke opname nodig zijn om onderlinge vergelijking van de resultaten mogelijk te maken.

Daarnaast kan elke opdrachtgever of uitvoerende partij dit verder uitbreiden met andere voor hem of haar van belang zijnde aspecten.

Het ontwikkelen van gedetailleerde protocollen voor de logistieke uitvoering van de opnames in het veld en voor de wijze van analyse van monitoringsgegevens behoort niet tot dit project. Ook het opstellen van richtlijnen voor beheeradviezen op basis van de resultaten van de monitoring behoort niet tot dit project. Het analyseren van de verkregen gegevens en het op basis daarvan opstellen van beheeradviezen kan het beste worden gedaan door partijen die de daarvoor benodigde expertisehebben. 


\section{Aanpak en werkwijze}

De aanpak binnen het project bestond uit 3 stappen:

1. Bureaustudie naar nationaal en internationaal beschikbare kennis rond bestaande richtlijnen en beoordelingssystematieken

- $\quad$ Beknopte inventarisatie van de in de wetenschappelijke literatuur beschikbare informatie

- Verzamelen van informatie en praktijkervaringen met het beoordelen van ETS van de bij het project betrokken bedrijven

2. Opstellen van een protocol voor de opname van ETS schadebeelden door middel van visuele inspectie

- Opstellen van een eerste concept

- $\quad$ Overleg met, en aanvulling door, bedrijfspartners in het project

- Aangepaste versie naar klankbordgroep voor commentaar

- Opstellen van de definitieve versie

- Illustratie van de representatieve aantastingscategorieën met eenduidige fotobeelden

3. Communicatie en publicatie omtrent het protocol

- Opstellen van een communicatieplan

- Uitvoeren van de communicatie

In het volgende hoofdstuk is toegelicht hoe het protocol tot stand is gekomen. Het uiteindelijke protocol voor uniforme beoordeling van ETS is separaat opgenomen in bijlage 2. Samen met een korte inleiding en een serie foto's ter illustratie van de verschillende ziekteklassen is deze bijlage geschikt om te worden gebruikt in de praktijk. 


\section{Resultaten}

Uit de projectbeschrijving, de discussie daarvan met de projectgroep tijdens de startbijeenkomst op 8 februari 2018 in Houten en een korte bespreking van het project tijdens de ISB bijeenkomst op 23 maart 2018 in Den Haag kwamen de volgende voorwaarden en restricties voor het te ontwikkelen protocol beoordeling ETS naar voren:

- Het gaat om ETS bij als straatboom geplant essen Het protocol wordt ontwikkeld voor het beoordelen van aantasting door ETS van essen (alle soorten en cultivars) die als straatboom zijn geplant; dit kunnen individuele bomen zijn, bomen in rijbeplantingen, in parken of in beplantingen langs wegen.

- Eenvoudig Het te ontwikkelen protocol is standaard voor de minimaal te verzamelen informatie betreffende ETS. Deze kan door opdrachtgevers of uitvoerende partijen naar wens worden uitgebreid met opnamekenmerken t.b.v. de boomveiligheidscontrole.

- Concreet

Het protocol moet zodanig geformuleerd zijn dat opdrachtgevers zich niet meer uitgebreid in de materie hoeven te verdiepen alvorens te bepalen wat ze moeten vragen aan de uitvoerders (het gaat om een kant en klaar protocol waar naar kan worden verwezen voor standaard beoordeling ETS).

- Mogelijkheid om de resultaten van verschillende opnames (verschillende locaties in het land of tijdstip) te vergelijken

Door altijd (minimaal) dezelfde gegevens te verzamelen op de in het protocol beschreven standaardwijze worden de op verschillende locaties of tijdstippen (herhalingen in de tijd) verzamelde gegevens vergelijkbaar. Zo wordt het mogelijk om een goed beeld te krijgen van ernst en ontwikkeling van ETS, zowel lokaal als regionaal of landelijk.

- Hanteerbaar in de praktijk (in het veld) Het protocol moet zo eenvoudig mogelijk zijn voor toepassing in de praktijk en mag niet te veel tijd kosten (vooral ontwikkeld voor praktijkgebruik, met daarnaast de mogelijkheid voor nader boomtechnisch en/of wetenschappelijk onderzoek).

- Resultaten eenvoudig te interpreteren

De verzamelde gegevens moeten door de boombeheerder eenvoudig, d.w.z. zonder de noodzaak van ingewikkelde bewerkingen, verwerkt kunnen worden tot eenduidige en zo concreet mogelijke resultaten.

- Voldoende informatie leveren

De resultaten moeten voldoende informatie leveren om te kunnen worden gebruikt als basis voor verdere beheer- en beleidsplannen aangaande het huidige en toekomstige beheer van essenbeplantingen.

- Wetenschappelijk onderbouwd Om de resultaten ook te kunnen relateren aan ontwikkelingen buiten Nederland dient het protocol aan te sluiten bij de beschikbare (internationale) wetenschappelijke kennis.

- Landelijk toepasbaar

Het protocol moet in het hele land toepasbaar zijn om een goed beeld te krijgen van de impact van ETS bij de als straatboom geplante essen in Nederland en om een betrouwbare inschatting en/ of analyse te kunnen maken van de te verwachten ontwikkelingen (verloop van sterfte en uitval). 


\subsection{Beschikbare informatie I nternationale literatuur}

In de loop der jaren zijn in verschillende landen systemen ontwikkeld om de mate van aantasting door ETS vast te leggen. In 2014 bestonden al (minimaal) 10 protocollen (Kopinga, 2014, pers. mededeling). Deze zijn alle gebaseerd op klassen of categorieën, weergegeven als 'score' in cijfers of percentages. Inmiddels bekende, in de internationale wetenschappelijke literatuur beschreven, systemen om de mate van aantasting door ETS vast te leggen zijn de systemen van onder meer Alfas Pliura in Litouwen (Pliura et al. 2011), Thomas Kirisits in Oostenrijk (Kirisits \& Freinschlag 2012) en Rasmus Enderle (Enderle et. al, 2015) in Duitsland.

Het systeem van Pliura is gebaseerd op het totaalbeeld van de (jonge) boom, d.w.z. de combinatie van zichtbare symptomen. Het systeem loopt van 5 (gezond) via lichte, matige en sterke aantasting naar 1 (dood) of 0 (na aanplant niet meer uitgelopen). De andere 2 scoringsystemen zijn gebaseerd op het indelen in klassen van het deel (percentage) van de kroon met schade door ETS waarbij de grenzen van de klassen in de verschillende systemen onderling verschillen. Taksterfte (afgestorven twijgen, takken of zelfs een deel van de stam), al dan niet gecombineerd met bladverlies en de aanwezigheid van waterloten, zijn centrale elementen in de scoringsystemen. Tabel 1 geeft de belangrijkste kenmerken van de genoemde systemen.

Tabel 1 Belangrijkste kenmerken van enkele bekende internationaal gebruikte systemen voor de beoordeling van ETS.

\begin{tabular}{|c|c|c|c|}
\hline Auteur & Pliura & Kirisits & Enderle \\
\hline Leeftijd bomen (jaar) & 8 & $16-17$ & $15-20$ \\
\hline Tijdstip beoordeling & Niet vermeld & $\begin{array}{l}\text { Midden mei } \\
\text { Eind juli } \\
1^{\mathrm{e}} \text { helft september }\end{array}$ & Juli-begin augustus \\
\hline Gescoorde kenmerk & Geheel van symptomen & $\begin{array}{l}\text { 1. Tak- \& twijgsterfte } \\
\text { 2. Bladverlies }\end{array}$ & $\begin{array}{l}\text { 1. Afwezig blad } \\
\text { 2. Waterlot }\end{array}$ \\
\hline Systeem & (Beeld)klassen & Klassen o.b.v. \% & Klassen o.b.v. \% \\
\hline Klassen & $\begin{array}{l}\text { 5. Geen aantasting } \\
\text { 4. Licht aangetast } \\
\text { 3. Matig aangetast } \\
\text { 2. Zwaar aangetast } \\
\text { 1. Dood } \\
\text { 0. Dood na planten }\end{array}$ & $\begin{array}{l}\text { 0. Geen } \\
\text { 1. }<5 \\
\text { 2. }>5-20 \\
\text { 3. }>20-50 \\
\text { 4. }>50-80 \\
\text { 5. }>80-100 \\
\text { 6. } 100\end{array}$ & $\begin{array}{l}\text { 0. Geen } \\
\text { 1. } 1-10 \\
\text { 2. } 11-25 \\
\text { 3. } 26-60 \\
\text { 4. } 61-99\end{array}$ \\
\hline
\end{tabular}

Deze systemen werden ontwikkeld in het kader van het zoeken naar minder vatbare selecties/individuen of herkomsten van Fraxinus excelsior voor gebruik in de bosbouw. Ze worden gebruikt voor het beoordelen van individuele bomen in proefvelden met zaailingen van geselecteerde herkomsten of klonaal vermeerderde selecties. Daarbij gaat het om relatief jonge bomen ( 8 - 20 jaar) in proefvelden. De scoringssystemen zijn dus niet ontwikkeld voor bomen van allerlei leeftijden in het stedelijk en landelijk gebied waarbij risicomanagement een belangrijk aandachtspunt is. Desondanks zijn ze als uitgangspunt voor een uniform protocol voor het beoordelen van ETS in het stedelijk gebied goed bruikbaar. 
Bij het schatten van het deel van de kroon dat door ETS is afgestorven aan de hand van de mate van bladverlies of het percentage van bladbezetting zijn er in de loop van het seizoen twee complicerende ontwikkelingen:

1. Aangetaste bomen vormen vaak veel waterlot op de nog levende delen. Hierdoor kan de kroon, met name later in het groeiseizoen, er op het eerste gezicht nog goed groen uit zien terwijl er toch een aanzienlijk deel van de oorspronkelijke kroon door ETS is afgestorven. Enderle et al. (2015) schatten daarom (met dezelfde schaal) ook de hoeveelheid waterlot in de beoordeelde bomen.

2. Een tweede ontwikkeling die het schatten van de mate van tak- en twijgsterfte met name laat in het groeiseizoen bemoeilijkt is het vroegtijdig afvallen van door $\mathrm{H}$. fraxineus geïnfecteerde bladeren.

In het voorjaar en vroege zomer worden door vruchtlichamen van de schimmel op afgevallen bladstelen uit het vorige jaar sporen geproduceerd die in de loop van de zomer nieuwe bladinfecties veroorzaken (zie de ziektecyclus in bijlage 1). Vanwege de hierdoor veroorzaakte bladval later in het seizoen geven Kirisits \& Freinschlag (2012) aan dat beoordeling van het percentage kroonsterfte in september minder betrouwbare resultaten geeft. Om die reden is de voorkeursperiode voor de beoordeling van ETS in de maanden juni $\mathrm{t} / \mathrm{m}$ augustus. Echter, door seizoensinvloeden kan in sommige gevallen in september ook nog een beoordeling van ETS worden gedaan. Dit is door ETS deskundigen te beoordelen.

\subsection{Ervaringen in Nederland}

In Nederland gebruiken zowel BTL Bomendienst als Terra Nostra voor het beoordelen van ETS het systeem van Kirisits om de mate van bladverlies te kwantificeren. Daarnaast gebruiken beide bedrijven, om de mate en aard van taksterfte in de boom te classificeren, ook het systeem van Pliura. Terra Nostra beoordeelt bovendien specifiek de mate van waterlotvorming waarmee het vermogen van de boom om het bladoppervlakte op peil te houden wordt gekwantificeerd.

In een onderzoek in de gemeente Amsterdam (Kopinga \& De Vries, 2017) werden drie methoden naast elkaar gebruikt (Kirisits, Pliura, Enderle) en de resultaten vergeleken. Daarbij werd geconcludeerd dat de Kirisits methode de verschillende aantastingscategorieën het nauwkeurigst onderscheidt; maar dat het gevonden aantastingspercentage ETS slechts ten dele de waargenomen conditie van de bomen verklaart. Er zijn duidelijk meer factoren die daar invloed op hebben, waaronder de groeiplaats. Het is daarom voor een goede interpretatie van de resultaten belangrijk om naast het scoren van de mate van aantasting door ETS ook de algemene conditie van de boom, het al dan niet aanwezig zijn van ETS en de belangrijkste omgevingsfactoren en boomkenmerken vast te leggen. In verband met de te nemen beheermaatregelen met betrekking tot boomveiligheid en risicoklassen stellen Kopinga en De Vries (2017) verder dat het van belang is om ook de diameter van afgestorven takken in de kroon vast te leggen.

\subsection{Keuze uitgangspunt protocol voor uniforme beoordeling essentaksterfte}

De systemen van Kirisits en Pliura worden internationaal veel gebruikt en zijn in de afgelopen jaren ook in Nederland als blauwdruk voor opnamesystemen gebruikt. Hierover is o.a. binnen het EU FRAXBACK programma gerapporteerd (Kopinga \& de Vries, 2017). Deze twee systemen zijn daarom als uitgangspunt gekozen voor het in dit document beschreven protocol. Voor de combinatie van deze twee systemen is gekozen vanwege het verschil in uitgangspunt in de wijze waarop het systeem de mate van aantasting vast legt. Het systeem van Kirisits is een kwantitatief systeem dat de mate van aantasting (het deel van de kroon dat schade heeft als gevolg van ETS) uitdrukt als percentage van de oorspronkelijke kroon. Het systeem van Pliura is een kwalitatief systeem dat het stadium van de aantasting (hoe ver is de ziekte voortgeschreden in de boom) weergeeft. Daarmee vullen de systemen elkaar aan en geven samen een completer beeld van de toestand van de betreffende boom dan ieder apart. 


\subsection{Protocol uniforme beoordeling essentaksterfte}

\subsubsection{Uitgangspunten}

- Het protocol dient om voldoende, en voldoende gedetailleerde, informatie te kunnen verzamelen over de mate van aantasting van essen door ETS. Hiermee kan de mate van aantasting van essen door ETS van zowel individuele bomen als van een populatie essen worden gevolgd en vergeleken.

- Het is belangrijk dat de waarnemer er zeker van is dat er sprake is van ETS. De waarnemer moet ervaring hebben in het beoordelen van deze boomziekte. De grote variatie van uitingsvormen van ETS in de praktijk maakt het nodig dat de waarnemer is 'geschoold' in het herkennen van ETS en het werken met dit protocol.

- De meest aangewezen manier om de mate van aantasting te kwantificeren is door het schatten van het deel van de kroon waar het blad ontbreekt op plaatsen waar het bij een niet aangetaste boom wel aanwezig zou zijn, gecombineerd met zowel een klasse-indeling van de voortgang van de aantasting door ETS als de mate waarin de boom reageert met waterlotvorming.

- Het systeem van Kirisits (Kirisits \& Freinslag, 2012) is geschikt voor het vastleggen van zowel de mate van bladverlies als de mate van waterlotvorming. Het protocol maakt gebruik van dit systeem, maar wel met een aanpassing. In het protocol wordt de kroon als geheel beoordeeld. Kirisits verdeelt de kroon in 3 delen om daarvan het gemiddelde te bepalen. Mocht de waarnemer het prettiger vinden om de kroon in 3 lagen te verdelen om de mate van ETS te kunnen inschatten dan mag dat, maar het is niet nodig.

- In dit protocol wordt bij de indeling in bladverlies niet het onderscheid gemaakt tussen blad dat aanwezig is en eventueel nieuw blad dat door waterlotvorming is ontstaan omdat het onderscheid in de praktijk meestal niet te maken is.

- $\quad$ Om een indruk te krijgen van de mogelijkheden van herstel van aangetaste bomen wordt m.b.v. de methode van Pliura ook geregistreerd hoever het door ETS veroorzaakte ziekteproces in de boom is voortgeschreden (beperkt tot het blad, in de bladstelen, twijgsterfte, sterfte van gesteltakken, tot in de stam) en daarnaast de mate van herstel via de vorming van waterlot.

- Voor het monitoren van ETS in de loop van de tijd is het belangrijk om het type omgeving (verkeersweg, woonstraat, park, etc.) en het type groeiplaats (in verharding, in gras, in beplanting etc., waarin wordt uitgegaan dat meer dan $50 \%$ van de kroonprojectie bepaalt welk type groeiplaats wordt gekozen. Hiermee kunnen mogelijke invloeden van omgevingsfactoren op het optreden van ETS worden geanalyseerd.

- Voor groenbeheerders is het gevaar dat kan ontstaan door uitvallende takken doorgaans ook een serieus punt van aandacht. Daarom wordt in dit protocol ook geregistreerd of er afgestorven takken aanwezig zijn, en zo ja in welke afmeting. Vanuit zorgplicht, zie stadsbomenvademecum, is de ondergrens voor afgestorven hout $4 \mathrm{~cm}$ doorsnee en 1 meter lang. Bij meerjarige monitoring kan dit ook inzicht geven in de snelheid waarmee afgestorven takken worden gevormd in de verschillende aantastingscategorieën.

- In dichte beplantingen of bij slechte toegankelijkheid kan het voorkomen dat het niet goed mogelijk is om de mate van bladverlies te scoren m.b.v. de methode van Kirisits. In dergelijke gevallen kan die vraag worden overgeslagen en volstaat de beoordeling van het stadium van aantasting m.b.v. de methode van Pliura. 


\subsubsection{Op te nemen gegevens Algemene gegevens}

1. Datum van beoordeling (ddmmyyyy)

2. Locatie boom (X/Y coördinaten, volgens standaard EPSG 28992 coördinatensysteem)

3. Waarnemer (bedrijf + naam waarnemer)

\section{Gegevens groeiplaats}

4. Type beplanting: solitaire boom/ laanbeplanting/ plantsoen/ bomen in bosverband

5. Type standplaats: (half)verharding/ gazon/ ruig gras/ gesloten beplanting/ open grond.

Bepalend hierin is de standplaats waar meer dan $50 \%$ van de kroonprojectie zich bevindt.

\section{Boomgegevens}

6. Boomnummer (uniek)

7. Boomsoort en eventueel cultivar

8. Plantjaar (uit boomregistratiesysteem of inschatten)

9. Diameter op $1.30 \mathrm{~m}$ hoogte

10. Algehele conditie: volgens schaal Stadsbomenvademecum, zie tabel hieronder.

\begin{tabular}{|l|l|}
\hline Conditieklasse & Kenmerken \\
\hline Goed & $\begin{array}{l}\text { Boom vertoont gewenste (optimale) soortspecifieke groei, wat zichtbaar is aan de } \\
\text { goede twijggroei en knopontwikkeling. De boom vertoont het beeld dat van de } \\
\text { soort verwacht mag worden onder goede groeiomstandigheden en op een goede } \\
\text { groeiplaats. }\end{array}$ \\
\hline Redelijk & $\begin{array}{l}\text { Boom vertoont niet optimale groei, wat zichtbaar is aan de verminderde } \\
\text { scheutlengte en de meer transparante kroon als gevolg van verminderde } \\
\text { ontwikkeling van zijknoppen. De verminderde (groei) omstandigheden hebben nog } \\
\text { geen duidelijke negatieve gevolgen voor de verdere ontwikkeling. }\end{array}$ \\
\hline Matig & $\begin{array}{l}\text { Boom verkeert in een (sterk) verminderde conditie, wat zichtbaar is aan de } \\
\text { transparante kroon door (deels) afstervende twijgen, matige twijggroei, } \\
\text { afstervende takuiteinden en regeneratiegroei op hoofdgesteltakken. De } \\
\text { levensverwachting van de boom is (sterk) verminderd. Het proces is echter nog } \\
\text { omkeerbaar. }\end{array}$ \\
\hline Slecht & $\begin{array}{l}\text { De boom vertoont duidelijke signalen van algehele aftakeling, wat zichtbaar is aan } \\
\text { forse kroonsterfte en zeer beperkte groei. De levensverwachting van de boom is } \\
\text { ernstig verminderd. Duidelijk aftakelende boom, waarbij veelal sprake is van een } \\
\text { ijle kroon, met scheutsterfte resulterend in veel en soms dikke afgestorven takken. }\end{array}$ \\
\hline Zeer slecht & \begin{tabular}{l} 
De boom is op sterven na dood. \\
\hline
\end{tabular} \\
\hline
\end{tabular}

11. In afgelopen 3 jaar gesnoeid: ja/ nee

12. Aantasting door Armillaria spp. (honingzwam): ja/ nee

13. Andere ziekten, aantastingen of beschadigingen:

\section{Gegevens essentaksterfte (ETS)}

14. Tak-/twijgsterfte aanwezig: ja/ nee

15. Is het ETS: ja/ twijfel/ nee

16. Hoe ver is de aantasting waarneembaar: blad/ twijgen/ takken/ gesteltakken/ stam 
17. Percentage bladverlies ten opzichte van de originele kroon ongeacht of aanwezig blad oud of nieuw gevormd is. Zie tabel ziekteklasse hieronder. De bijbehorende beelden zijn terug te vinden in bijlage 2 op nummer.

Ziekteklassen te gebruiken voor het scoren van bladverlies (ontbrekend blad) (gebaseerd op het systeem van Kirisits \& Freinschlag, 2012).

\begin{tabular}{|c|c|c|}
\hline $\begin{array}{l}\text { Ziekteklasse/ } \\
\text { bladverlies }\end{array}$ & $\begin{array}{l}\text { Aangetast deel kroon/ percentage } \\
\text { ontbrekend deel bladvolume }\end{array}$ & $\begin{array}{c}\text { Afbeelding bladverlies/ } \\
\text { fotonummer }\end{array}$ \\
\hline 0 & $0 \%$ (geen symptomen) & 2 \\
\hline 1 & $<5 \%$ & 3 \\
\hline 2 & $5-20 \%$ & 4 \\
\hline 3 & $21-50 \%$ & 5 \\
\hline 4 & $51-80 \%$ & 6 \\
\hline 5 & $81-99 \%$ & 7 \\
\hline 6 & $100 \%$ & 2 \\
\hline
\end{tabular}

18. Percentage van het aanwezige blad dat het gevolg is van waterlotvorming, geschat volgens klassen indeling van Kirisits. Zie tabelpercentage blad door waterlotvorming hieronder. De bijbehorende beelden zijn terug te vinden in bijlage 2 op nummer.

Percentage blad door waterlotvorming, verdeeld in 6 klassen (gebaseerd op het systeem van Kirisits \& Freinschlag, 2012).

\begin{tabular}{|c|c|c|}
\hline Klasse & $\begin{array}{c}\text { Percentage nieuw blad afkomstig van } \\
\text { waterloten. }\end{array}$ & Fotonummer \\
\hline 0 & $0 \%$ (geen waterlot) & 8 \\
\hline 1 & $<5 \%$ & 9 \\
\hline 2 & $5-20 \%$ & 10 \\
\hline 3 & $21-50 \%$ & 11 \\
\hline 4 & $51-80 \%$ & 12 \\
\hline 5 & $81-99 \%$ & 13 \\
\hline 6 & $100 \%$ & 8 \\
\hline
\end{tabular}

19. Aanwezigheid afgestorven plekken bast op stam (bastaantasting): $0 / 1 / 2 /$ meer dan 2

20. Aanwezigheid afgestorven takken, dikker dan $4 \mathrm{~cm} /$ of dunner dan $4 \mathrm{~cm}$ en langer dan $100 \mathrm{~cm}$ : ja/ nee

21. Maximale diameter afgestorven takken: schatten in $\mathrm{cm}$

22. Aftakelingsklasse volgens Pliura. Zie tabel ziekteklasse hieronder. De bijbehorende beelden zijn terug te vinden in bijlage 2 op nummer. 
Ziekteklassen gebaseerd op de voortgang van ETS in individuele bomen (gebaseerd op het systeem van Pliura et al. (2011) waarbij de nummering van de klassen is omgedraaid t.o.v. de originele indeling van Pliura).

\begin{tabular}{|c|c|c|c|c|}
\hline Ziekteklasse & Omschrijving & $\begin{array}{l}\text { Schematische } \\
\text { weergave }\end{array}$ & Beschrijving & Afbeelding \\
\hline 0 & $\begin{array}{l}\text { Geen } \\
\text { aantasting }\end{array}$ & & $\begin{array}{l}\text { Geen symptomen van aantasting } \\
\text { door ETS zichtbaar }\end{array}$ & 1 \\
\hline 1 & $\begin{array}{l}\text { Licht } \\
\text { aangetast }\end{array}$ & & $\begin{array}{l}\text { Beperkte symptomen op één of } \\
\text { enkele scheuten: bruin, verwelkt of } \\
\text { verdroogd blad en/of enkele } \\
\text { aantastingsplekken op twijgen of } \\
\text { stam }\end{array}$ & 14 \\
\hline 2 & $\begin{array}{l}\text { Matig } \\
\text { aangetast }\end{array}$ & & $\begin{array}{l}\text { Meerdere twijgen afgestorven, } \\
\text { afgestorven aantastingsplekken op } \\
\text { takken en/of stam en hergroei }\end{array}$ & 15 \\
\hline 3 & $\begin{array}{l}\text { Zwaar } \\
\text { aangetast }\end{array}$ & & $\begin{array}{l}\text { Groot deel van de scheuten en } \\
\text { eventueel ook deel van stam } \\
\text { afgestorven; meerdere afgestorven } \\
\text { aantastingsplekken op de stam en } \\
\text { hergroei vanuit de wortelhals }\end{array}$ & 16 \\
\hline 4 & Dood & & Boom geheel afgestorven & 17 \\
\hline
\end{tabular}





\section{Literatuur}

Enderle, R., Aikaterini Nakou, Kristina Thomas and Berthold Metzler, 2015; Annals of Forest Science (2015) 72:183-193. Susceptibility of autochthonous German Fraxinus excelsior clones to Hymenoscyphus pseudoalbidus is genetically determined.

Kirisits, T. and Christian Freinschlag, 2012. Ash dieback caused by Hymenoscyphus pseudoalbidus in a seed plantation of Fraxinus excelsior in Austria. Journal of Agricultural Extension and Rural Development Vol. 4(9), pp. 184-191, 14 May, 2012

Kopinga, J. and S.M.G. de Vries, 2017; Ash Dieback (ADB) in amenity trees in the city of Amsterdam development of a monitoring system and the first results of a large-scale survey in 2015. Pages 249-261 in: Vasaitis \& Enderle 2017. Dieback of European Ash (Fraxinus spp.) - Consequences and Guidelines for Sustainable Management.

McKinney, L.V., L.R. Nielsen, J.K. Hansen and E.D. Kjær, 2011. Presence of natural genetic resistance in Fraxinus excelsior (Oleraceae) to Chalara fraxinea (Ascomycota): an emerging infectious disease. Heredity (2011) 106, 788-797.

Pliüra, A., V. Lygis, V. Suchockas and E. Bartkevicius, 2011. Performance of Twenty Four European Fraxinus excelsior Populations in Three Lithuanian Progeny Trials with a Special Emphasis on Resistance to Chalara fraxinea. Baltic Forestry 17 (1): 17-34.

Prooijen, G.J . van, 2017. Stadsbomen Vademecum 3A: Boomcontrole en onderzoek. IPC Groene Ruimte 3e herz. dr., $164 \mathrm{p}$. 


\section{Bijlage 1 Ziektecyclus}

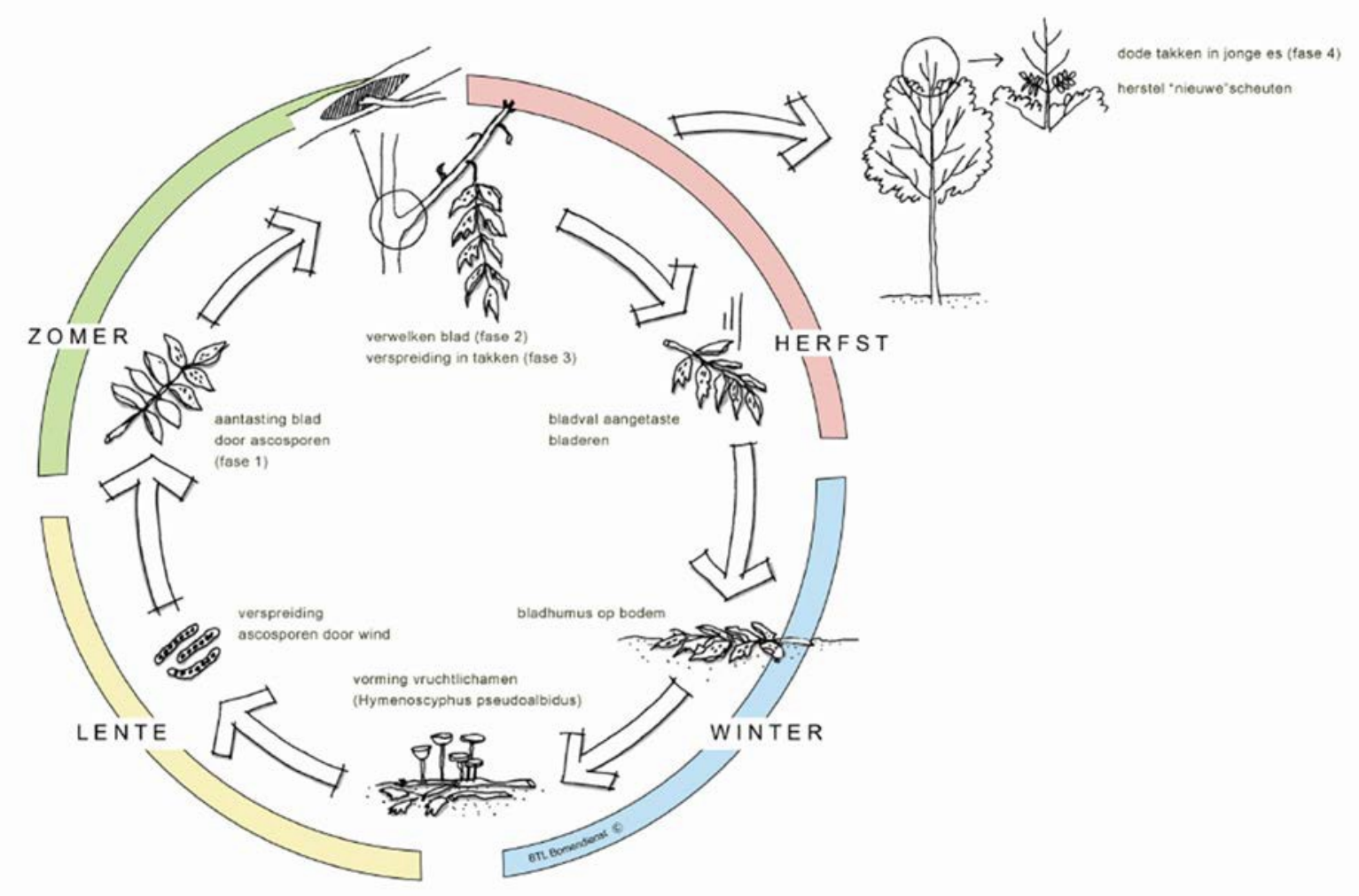

Bron: BTL Bomendienst 


\title{
Bijlage 2 Protocol voor uniforme beoordeling van essentaksterfte
}

\author{
Achtergrond van het protocol \\ Essentaksterfte (ETS) veroorzaakt door de schimmel Hymenoscyphus fraxineus is een relatief nieuwe \\ boomziekte die vanaf medio jaren 90 in Oost-Europa en vanaf ongeveer 2010 ook in Nederland in \\ toenemende mate leidt tot sterfte van essen (Fraxinus-soorten). De gewone es (Fraxinus excelsior) die in \\ Nederland, zowel in het buitengebied als in de stad, een veelgebruikte en daarmee belangrijke laan- en \\ straatboomsoort is, blijkt zeer gevoelig voor ETS. In de stedelijke en landelijke omgeving komen ook \\ andere Fraxinus soorten voor die in een aantal gevallen minder last lijken te hebben van ETS, maar een \\ compleet beeld hiervan ontbreekt nog. Verder is het microklimaat rond de boom in de stad niet \\ vergelijkbaar met die van een bosomgeving. Door deze verschillen is het verloop van de ziekte in es in \\ de stedelijke omgeving (nog) moeilijk in te schatten en de impact niet met zekerheid aan te geven. \\ Om een goede risico-inschatting te kunnen maken van de impact van ETS in de stedelijke omgeving zijn \\ veel waarnemingsgegevens nodig. Tot op heden gebruiken de meeste beheerders een vorm van visuele \\ inspectie om de boomveiligheid en gezondheid te beoordelen. In de praktijk worden verschillende \\ protocollen gebruikt, met onderling soms substantiële verschillen. De verzamelde data zijn hierdoor niet \\ uitwisselbaar en ook niet goed te vergelijken, dan wel wetenschappelijk te analyseren. $\mathrm{Er}$ is daarmee ook \\ nog geen volledig beeld van de ernst van ETS in heel Nederland. Daarom is in 2018 door het Platform \\ Boomspecialisten van de VHG, en de Intergemeentelijke Studiegroep Bomen (ISB) een project \\ geïnitieerd om te komen tot een landelijke protocol voor een uniforme beoordeling van ETS. Daarbij is \\ aan Wageningen UR gevraagd om op basis van de beschikbare wetenschappelijke informatie én \\ praktijkkennis ingebracht door Terra Nostra, BTL Boomadvies en Kopinga Boomadvies een protocol voor \\ uniforme opname van ETS op te stellen. Dit protocol is het resultaat daarvan.
}

\section{Toepasbaarheid}

Het protocol is bedoeld als een landelijke richtlijn voor het uniform beoordelen van de mate van aantasting van essen door ETS in de stedelijke en landelijke omgeving. Dat wil zeggen, een protocol dat gebruikt kan worden voor het beoordelen van ETS in stadsbomen en essen in beplantingen langs wegen (straat- en laanbomen). Het protocol beperkt zich tot ETS en is niet ontwikkeld voor andere ziekten of aantastingen.

Het protocol is bedoeld om te komen tot meer uniformiteit in het beoordelen van ETS zodat opnamegegevens van verschillende gebieden in de toekomst onderling vergelijkbaar worden. Het protocol beschrijft daarom een standaardwijze voor het waarnemen van de belangrijkste aspecten die bij elke beoordeling nodig zijn om onderlinge vergelijking van de resultaten mogelijk te maken. Daarnaast kan elke opdrachtgever of uitvoerende partij dit verder uitbreiden met voor hem of haar andere van belang zijnde aspecten. Het analyseren van de verkregen data en het op basis daarvan opstellen van beheeradviezen is geen onderdeel van het protocol, het protocol beperkt zich tot standaardisatie van het verzamelen van de daarvoor benodigde gegevens. De uitwerking behoort tot de expertise van de uitvoerende partijen.

Het protocol bestaat uit 22 in te voeren velden per boom. Van de 22 velden zitten er 2 in de vaste data (locatie, boomnummer). 2 velden worden automatisch gevuld (datum en waarnemer). Vanuit de administratieve informatie kunnen 3-4 velden overgenomen worden (boomsoort, type standplaats (mogelijk type beplanting) en plantjaar). Er blijven dan 14-15 velden over die ingevuld moeten worden. Veelal werkt men met het aanvinken van keuzevelden. NB: niet alle velden hoeven altijd ingevuld te worden. Bij bomen waarbij geen ETS aanwezig is hoeven veel velden dus ook niet gemuteerd te worden. Hierdoor blijft het praktisch uitvoerbaar. 
Het is wel belangrijk dat bij elke opname alle velden van het protocol worden gebruikt. Deze data moet worden ingewonnen om tenminste iets over aard, omvang en trends te kunnen zeggen, én om de gegevens met elkaar te delen. Heeft een opdrachtgever een ander doel, bv alleen maar een opname voor een snoeibestek, dan is deze niet verplicht om het protocol aan te houden.

De regelmaat van het beoordelen van de bomen wordt aan de boombeheerder overgelaten.

\section{Op te nemen gegevens}

\section{Algemene gegevens}

1. Datum van beoordeling (ddmmyyyy)

2. Locatie boom ( $X / Y$ coördinaten, volgens standaard EPSG 28992 coördinatensysteem)

3. Waarnemer (bedrijf + naam waarnemer)

\section{Gegevens groeiplaats}

4. Type beplanting: solitaire boom/ laanbeplanting/ plantsoen/ bomen in bosverband

5. Type standplaats: (half)verharding/ gazon/ ruig gras/ gesloten beplanting/ open grond. Bepalend hierin is de standplaats waar meer dan $50 \%$ van de kroonprojectie zich bevindt.

\section{Boomgegevens}

6. Boomnummer (uniek)

7. Boomsoort en eventueel cultivar

8. Plantjaar (uit boomregistratiesysteem of inschatten)

9. Diameter op $1.30 \mathrm{~m}$ hoogte

10. Algehele conditie: zie tabel 1.

11. In afgelopen 3 jaar gesnoeid: ja/ nee

12. Aantasting door Armillaria spp. (honingzwam): ja/ nee

13. Andere ziekten, aantastingen of beschadigingen:

\section{Gegevens essentaksterfte (ETS)}

14. Tak- /twijgsterfte aanwezig: ja/ nee

15. Is het ETS: ja/ twijfel/ nee

16. Hoe ver is de aantasting waarneembaar: blad/ twijgen/ takken/ gesteltakken/ stam

17. Percentage bladverlies ten opzichte van de originele kroon ongeacht of aanwezig blad oud of nieuw gevormd is. Zie tabel 2 . De bijbehorende beelden op nummer terug te vinden verderop in het protocol.

18. Percentage van het aanwezige blad dat het gevolg is van waterlotvorming. Zie tabel 3. De bijbehorende beelden zijn op nummer terug te vinden verderop in het protocol. 
19. Aanwezigheid afgestorven plekken bast op stam (bastaantasting): $0 / 1 / 2 /$ meer dan 2. Zie foto hieronder.

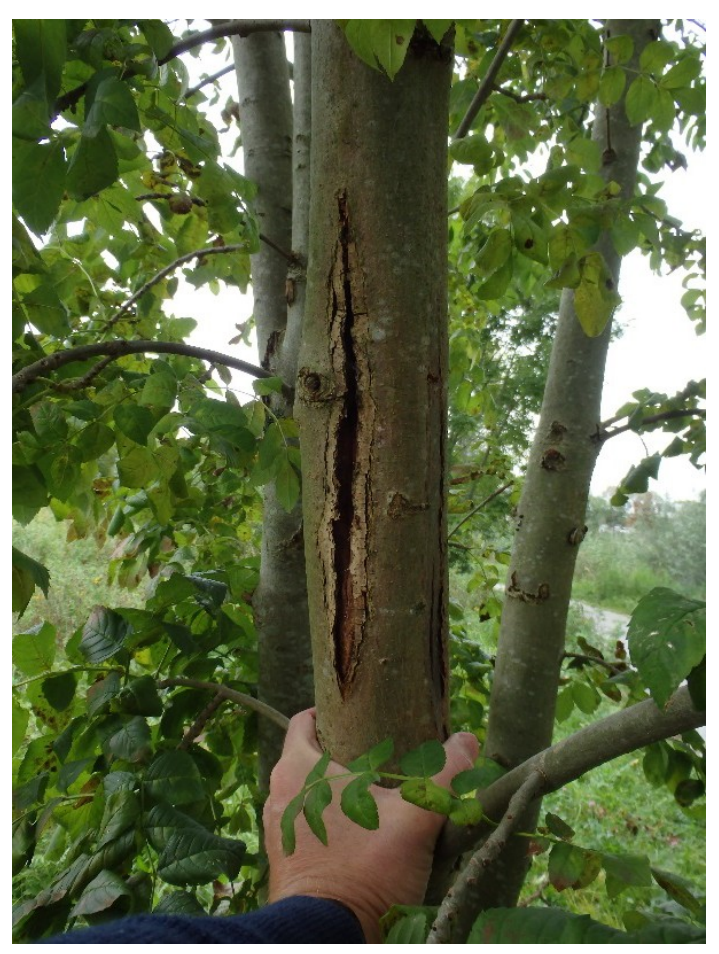

20. Aanwezigheid afgestorven takken, dikker dan $4 \mathrm{~cm} /$ of dunner dan $4 \mathrm{~cm}$ en langer dan $100 \mathrm{~cm}$ : ja/ nee

21. Maximale diameter afgestorven takken: schatten in $\mathrm{cm}$

22. Aftakelingsklasse. Zie tabel 4. De bijbehorende beelden zijn op nummer terug te vinden verderop in het protocol. 
Tabel 1. Conditieklassen met omschrijving van kenmerken.

\begin{tabular}{|c|c|c|}
\hline nummer & Conditieklasse & Kenmerken \\
\hline 1 & Goed & $\begin{array}{l}\text { Boom vertoont gewenste (optimale) soort-specifieke groei, wat zichtbaar } \\
\text { is aan de goede twijggroei en knopontwikkeling. De boom vertoont het } \\
\text { beeld dat van de soort verwacht mag worden onder goede } \\
\text { groeiomstandigheden en op een goede groeiplaats. }\end{array}$ \\
\hline 2 & Redelijk & $\begin{array}{l}\text { Boom vertoont niet optimale groei, wat zichtbaar is aan de verminderde } \\
\text { scheutlengte en de meer transparante kroon als gevolg van verminderde } \\
\text { ontwikkeling van zijknoppen. De verminderde (groei)omstandigheden } \\
\text { hebben nog geen duidelijke negatieve gevolgen voor de verdere } \\
\text { ontwikkeling. }\end{array}$ \\
\hline 3 & Matig & $\begin{array}{l}\text { Boom verkeert in een (sterk) verminderde conditie, wat zichtbaar is aan } \\
\text { de transparante kroon door (deels) afstervende twijgen, matige } \\
\text { twijggroei, afstervende takuiteinden en regeneratiegroei op } \\
\text { hoofdgesteltakken. De levensverwachting van de boom is (sterk) } \\
\text { verminderd. Het proces is echter nog omkeerbaar. }\end{array}$ \\
\hline 4 & Slecht & $\begin{array}{l}\text { De boom vertoont duidelijke signalen van algehele aftakeling, wat } \\
\text { zichtbaar is aan forse kroonsterfte en zeer beperkte groei. De } \\
\text { levensverwachting van de boom is ernstig verminderd. Duidelijk } \\
\text { aftakelende boom, waarbij veelal sprake is van een ijle kroon, met } \\
\text { scheutsterfte resulterend in veel en soms dikke afgestorven takken. }\end{array}$ \\
\hline 5 & Zeer slecht & De boom is op sterven na dood. \\
\hline
\end{tabular}

Tabel 2. Ziekteklassen te gebruiken voor het scoren van bladverlies (ontbrekend blad).

\begin{tabular}{|c|c|c|}
\hline $\begin{array}{c}\text { Ziekteklasse/ } \\
\text { bladverlies }\end{array}$ & $\begin{array}{c}\text { Aangetast deel kroon/ percentage ontbrekend deel } \\
\text { bladvolume }\end{array}$ & $\begin{array}{c}\text { Corresponderend } \\
\text { afbeeldingsnummer }\end{array}$ \\
\hline 0 & $0 \%$ (geen symptomen) & 1 \\
\hline 1 & $<5 \%$ & 2 \\
\hline 2 & $5-20 \%$ & 4 \\
\hline 3 & $21-50 \%$ & 5 \\
\hline 4 & $51-80 \%$ & 6 \\
\hline 5 & $81-99 \%$ & 7 \\
\hline 6 & $100 \%$ & 3 \\
\hline
\end{tabular}

Tabel 3. Percentage blad door waterlotvorming, verdeeld in 6 klassen

\begin{tabular}{|c|c|c|}
\hline klasse & Percentage blad afkomstig van waterlotvorming & $\begin{array}{c}\text { Corresponderend } \\
\text { afbeeldingsnummer }\end{array}$ \\
\hline 0 & (Geen symptomen) & 1 \\
\hline 1 & $<5 \%$ & 8 \\
\hline 2 & $5-20 \%$ & 9 \\
\hline 3 & $21-50 \%$ & 11 \\
\hline 4 & $51-80 \%$ & 12 \\
\hline 5 & $81-99 \%$ & 13 \\
\hline 6 & $100 \%$ & 10 \\
\hline
\end{tabular}


Tabel 4. Ziekteklassen gebaseerd op de voortgang van ETS in individuele bomen.

\begin{tabular}{|c|c|c|c|c|}
\hline Ziekteklasse & Omschrijving & $\begin{array}{c}\text { Schematische } \\
\text { weergave }\end{array}$ & Beschrijving & $\begin{array}{l}\text { Corresponderend } \\
\text { afbeeldingsnummer }\end{array}$ \\
\hline 0 & $\begin{array}{c}\text { Geen } \\
\text { aantasting }\end{array}$ & & $\begin{array}{c}\text { Geen symptomen van } \\
\text { aantasting door ETS } \\
\text { zichtbaar. }\end{array}$ & 1 \\
\hline 1 & $\begin{array}{c}\text { Licht } \\
\text { aangetast }\end{array}$ & & $\begin{array}{c}\text { Beperkte symptomen op } \\
\text { één of enkele scheuten: } \\
\text { bruin, verwelkt of } \\
\text { verdroogd blad en/of } \\
\text { enkele } \\
\text { aantastingsplekken op } \\
\text { twijgen of stam. }\end{array}$ & 14 \\
\hline 2 & $\begin{array}{c}\text { Matig } \\
\text { aangetast }\end{array}$ & & $\begin{array}{c}\text { Meerdere twijgen } \\
\text { afgestorven, afgestorven } \\
\text { aantastingsplekken op } \\
\text { takken en/of stam en } \\
\text { hergroei. }\end{array}$ & 15 \\
\hline 3 & $\begin{array}{c}\text { Zwaar } \\
\text { aangetast }\end{array}$ & & $\begin{array}{c}\text { Groot deel van de } \\
\text { scheuten en eventueel } \\
\text { ook deel van stam } \\
\text { afgestorven; meerdere } \\
\text { afgestorven } \\
\text { aantastingsplekken op de } \\
\text { stam en hergroei vanuit } \\
\text { de stambasis. }\end{array}$ & 16 \\
\hline 4 & Dood & & $\begin{array}{l}\text { Boom geheel } \\
\text { afgestorven. }\end{array}$ & 17 \\
\hline
\end{tabular}


Van alle klassen worden 2 foto's getoond, a en b. Foto's genomen door Henry Kuppen, Terra Nostra.

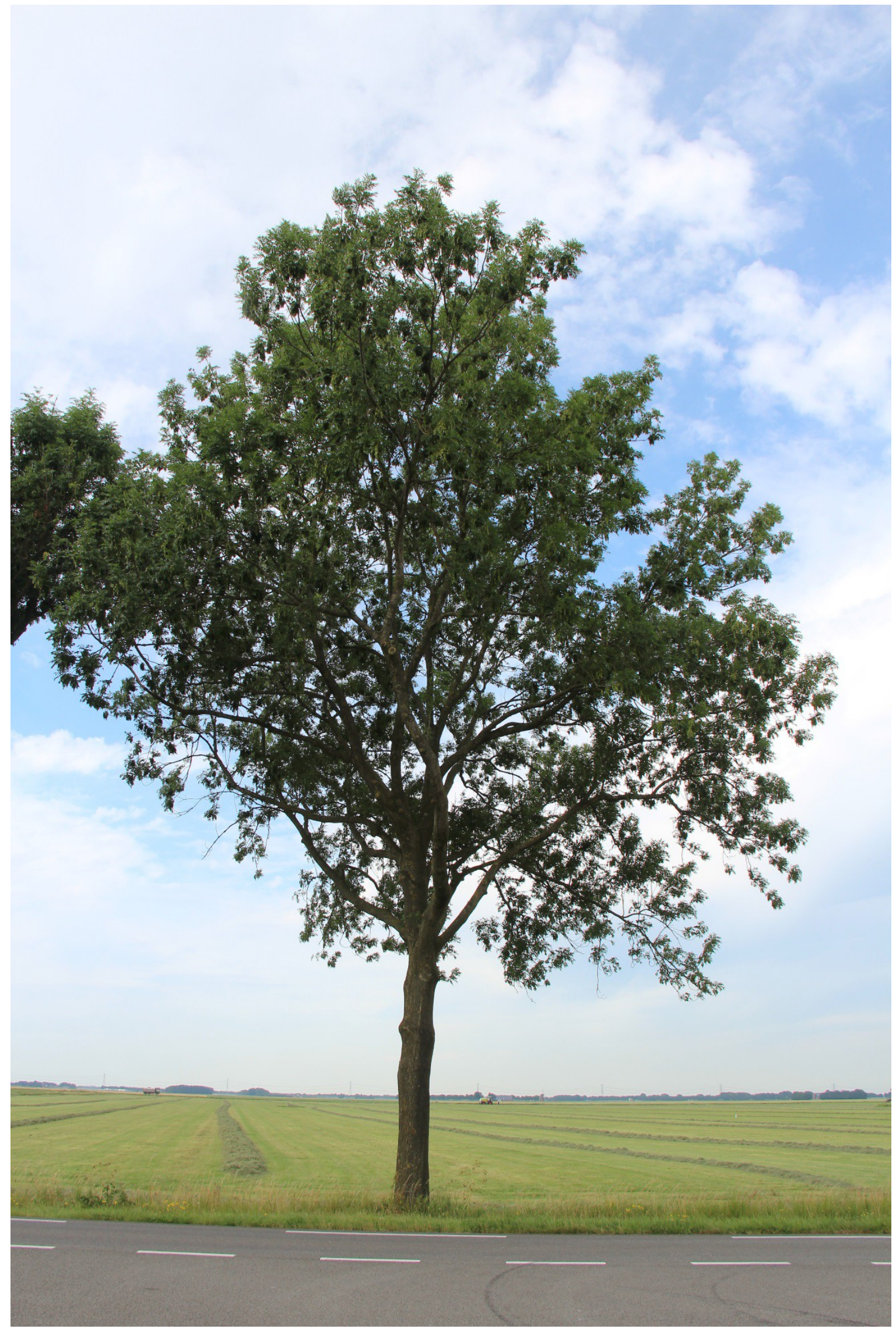

Foto 1a. Geen bladverlies, index 0 


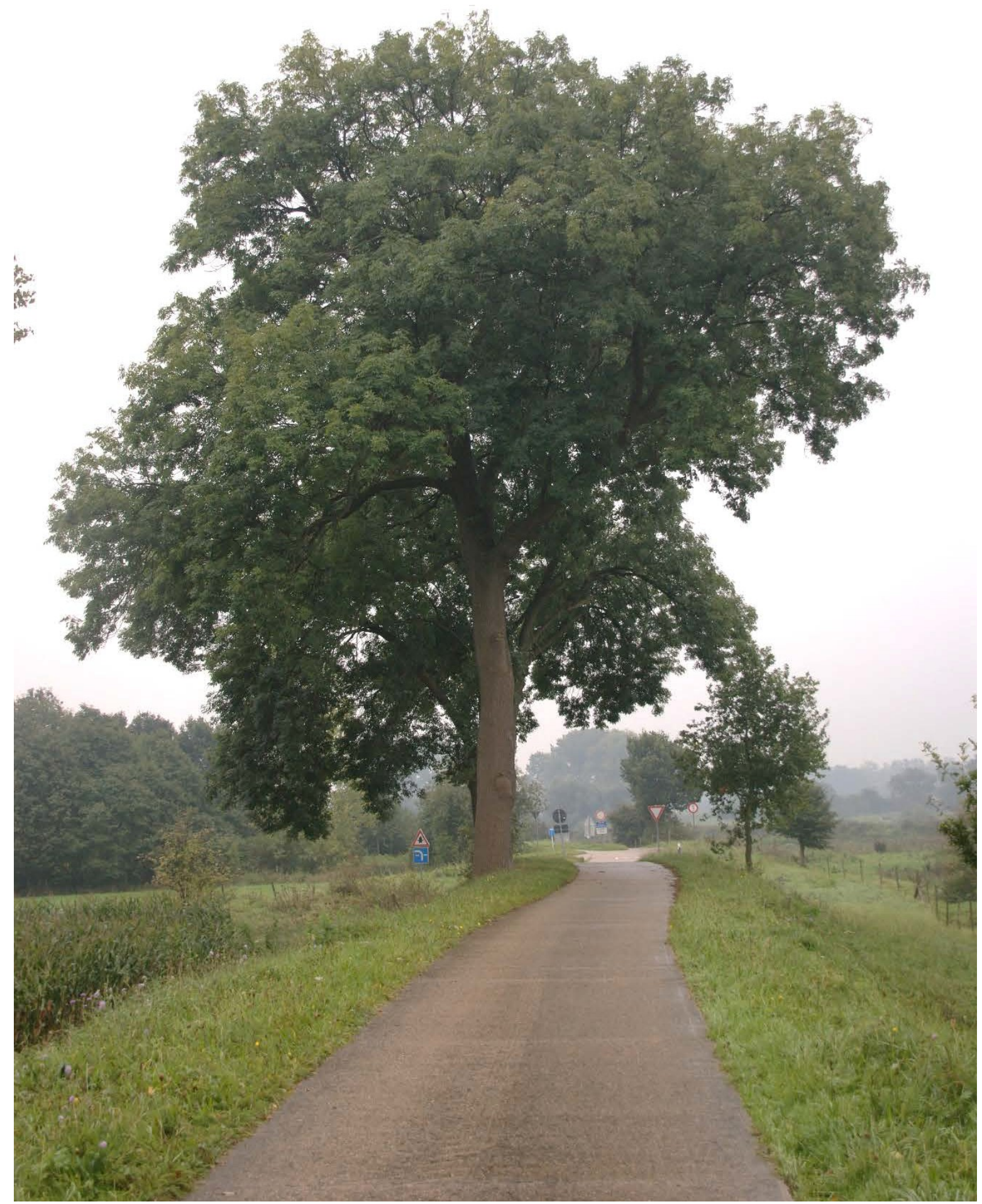

Foto 1 b. Geen bladverlies, index 0 


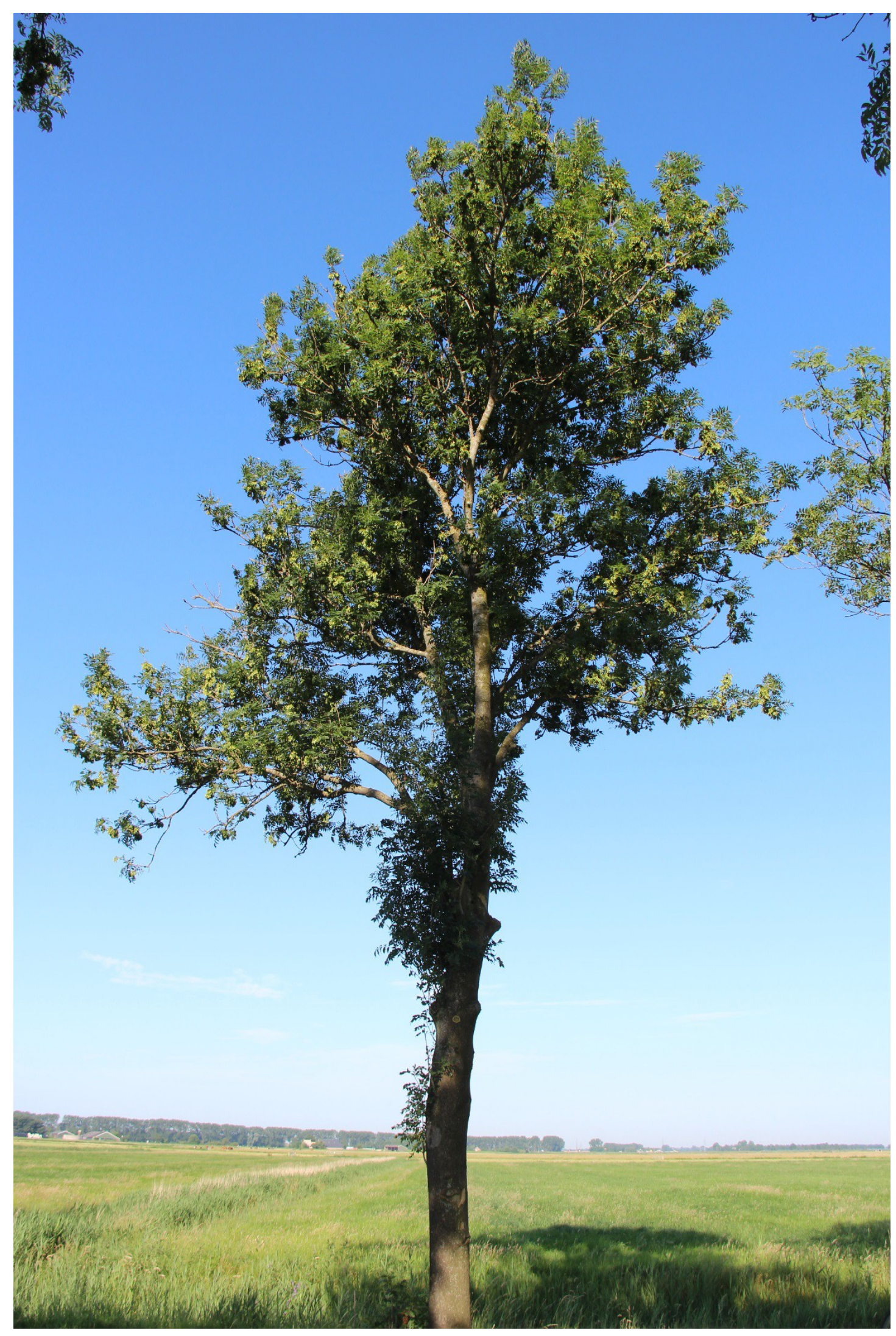

Foto 2 a. $<5 \%$ bladverlies, index 1 


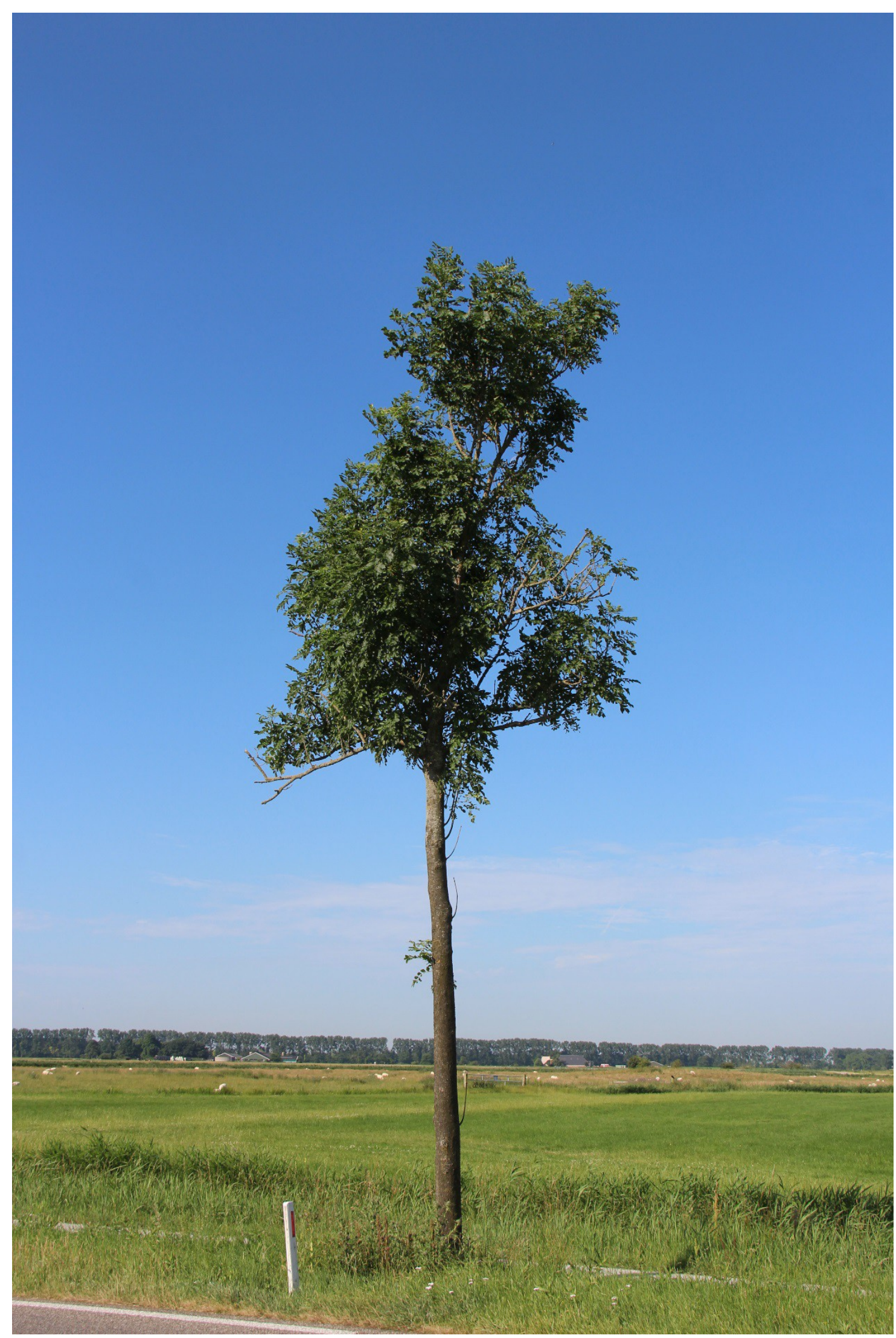

Foto 2 b. $<5 \%$ bladverlies, index 1 


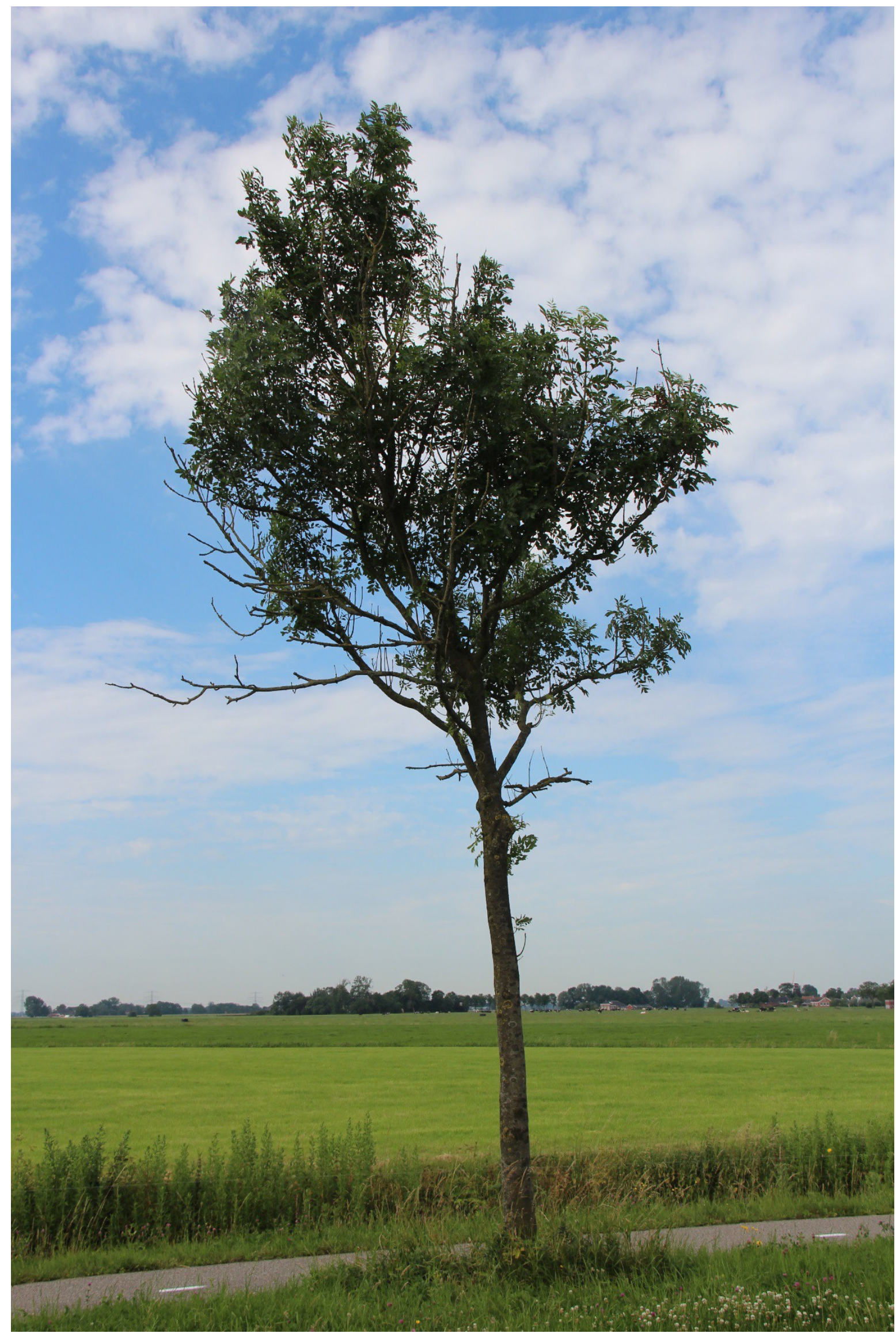

Foto 3a. Bladverlies $5-20 \%$, index 2 


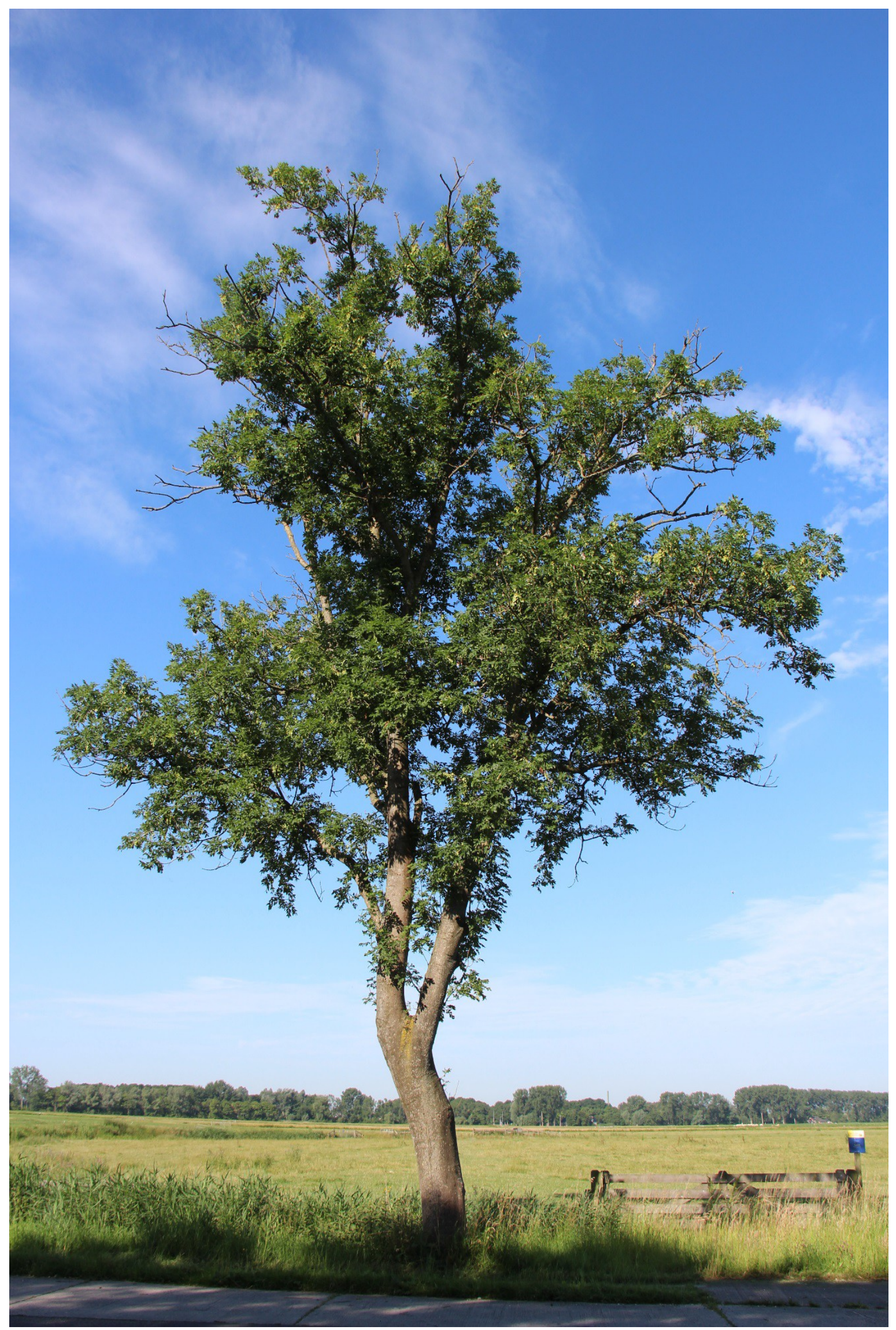

Foto 3b. Bladverlies 5-20\%, index 2 


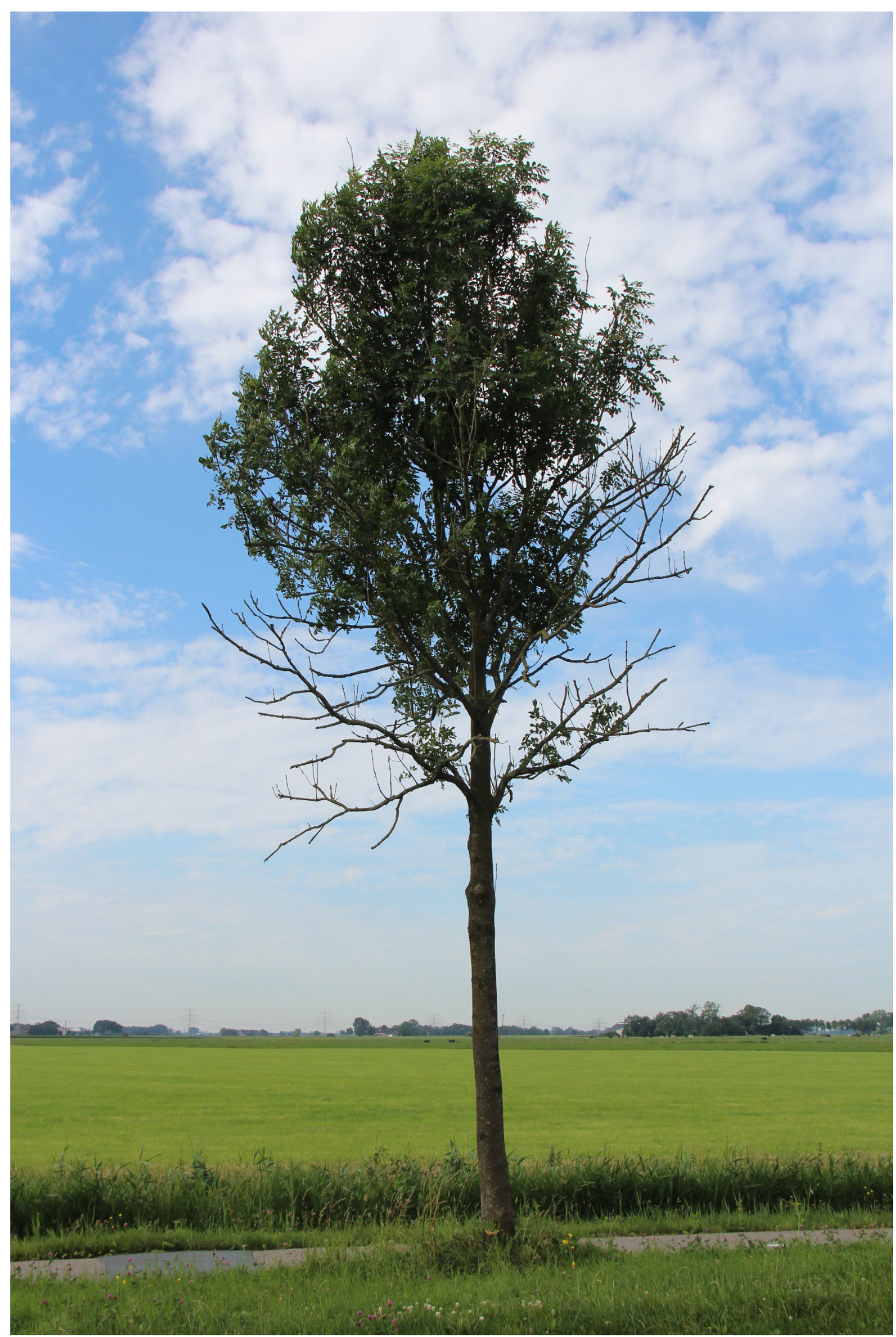

Foto $4 a$. Bladverlies $21-50 \%$, index 3 


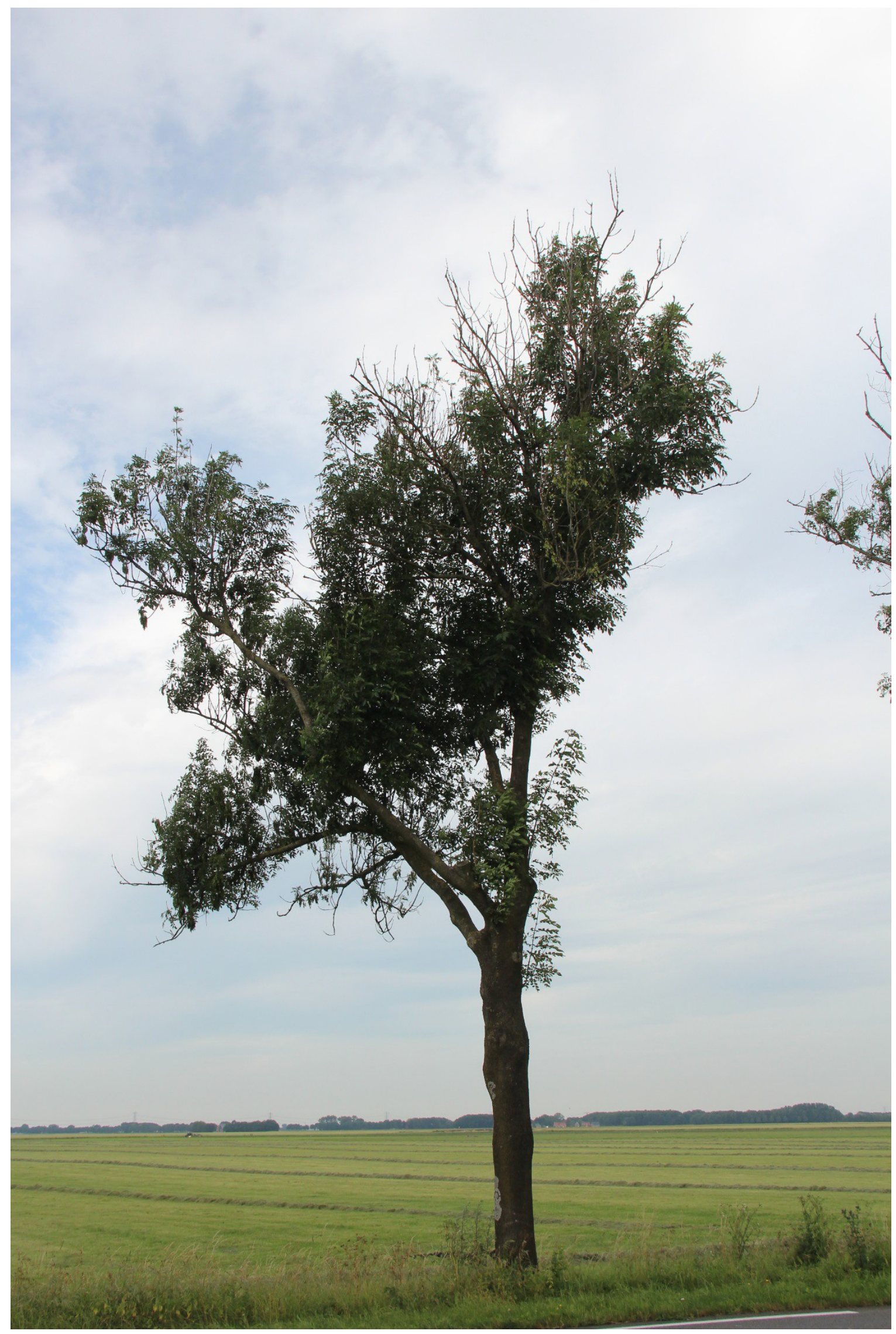

Foto 4b. Bladverlies $21-50 \%$, index 3 


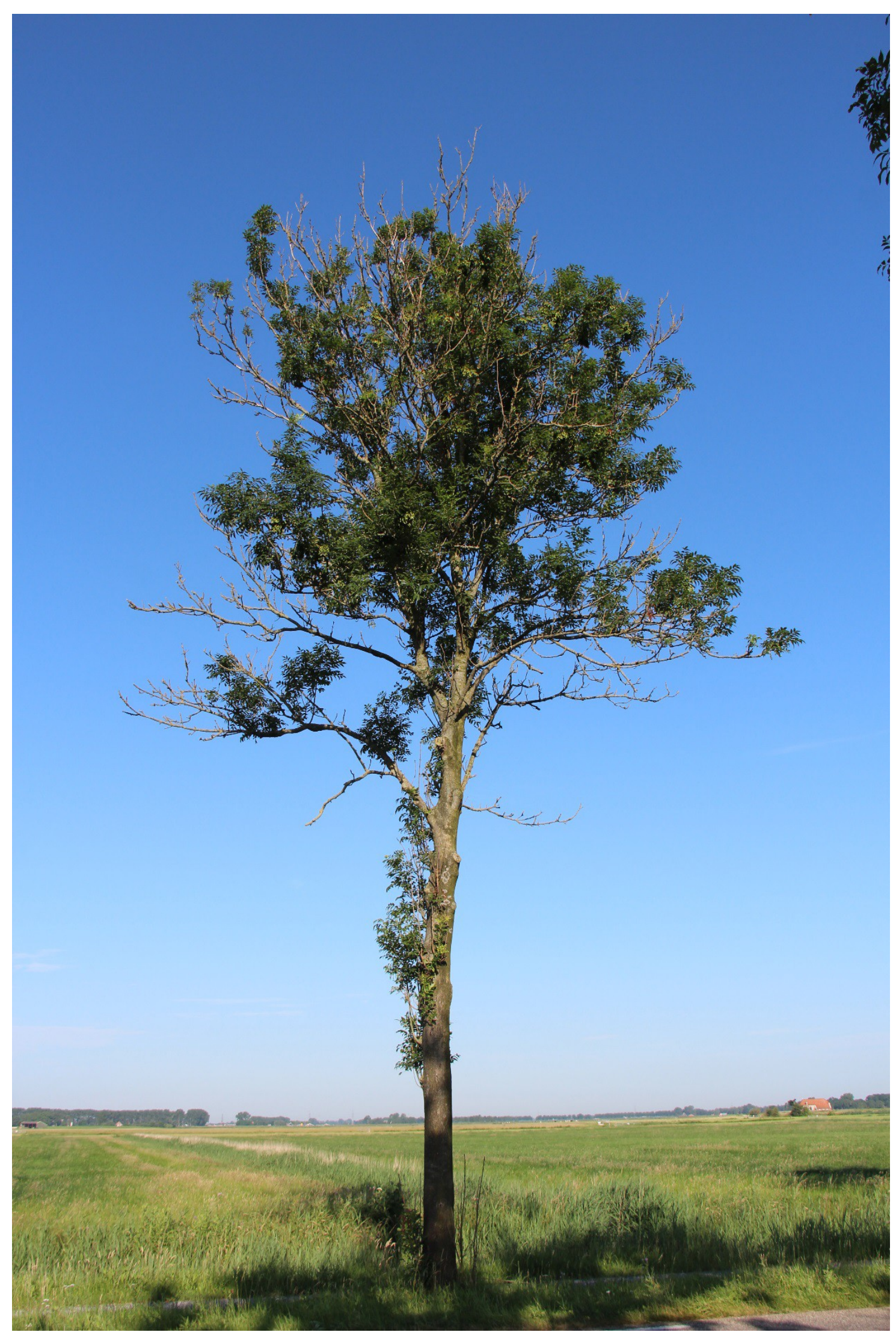

Foto 5a. Bladverlies 51-80\%, index 4 


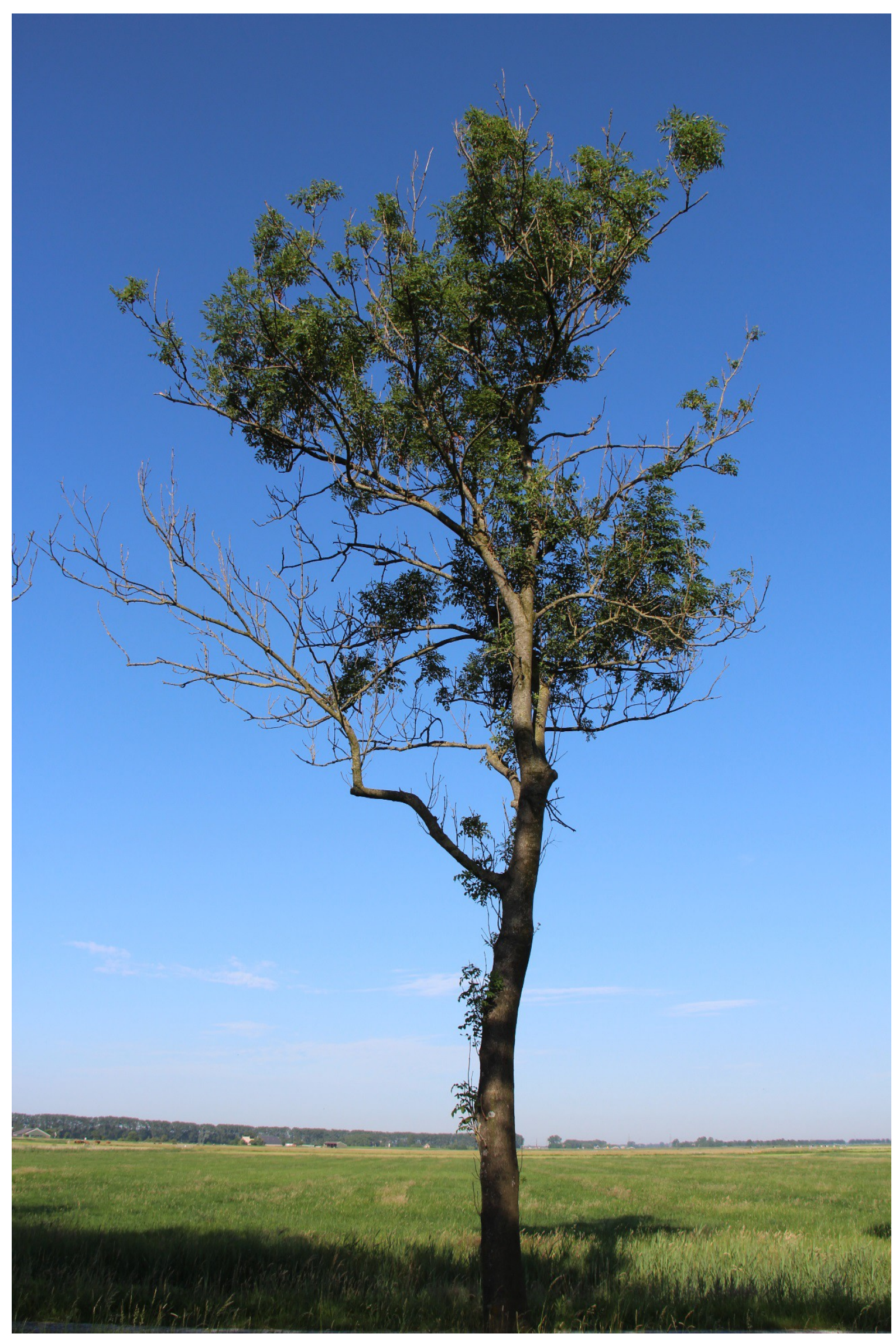

Foto 5b. Bladverlies $51-80 \%$, index 4 


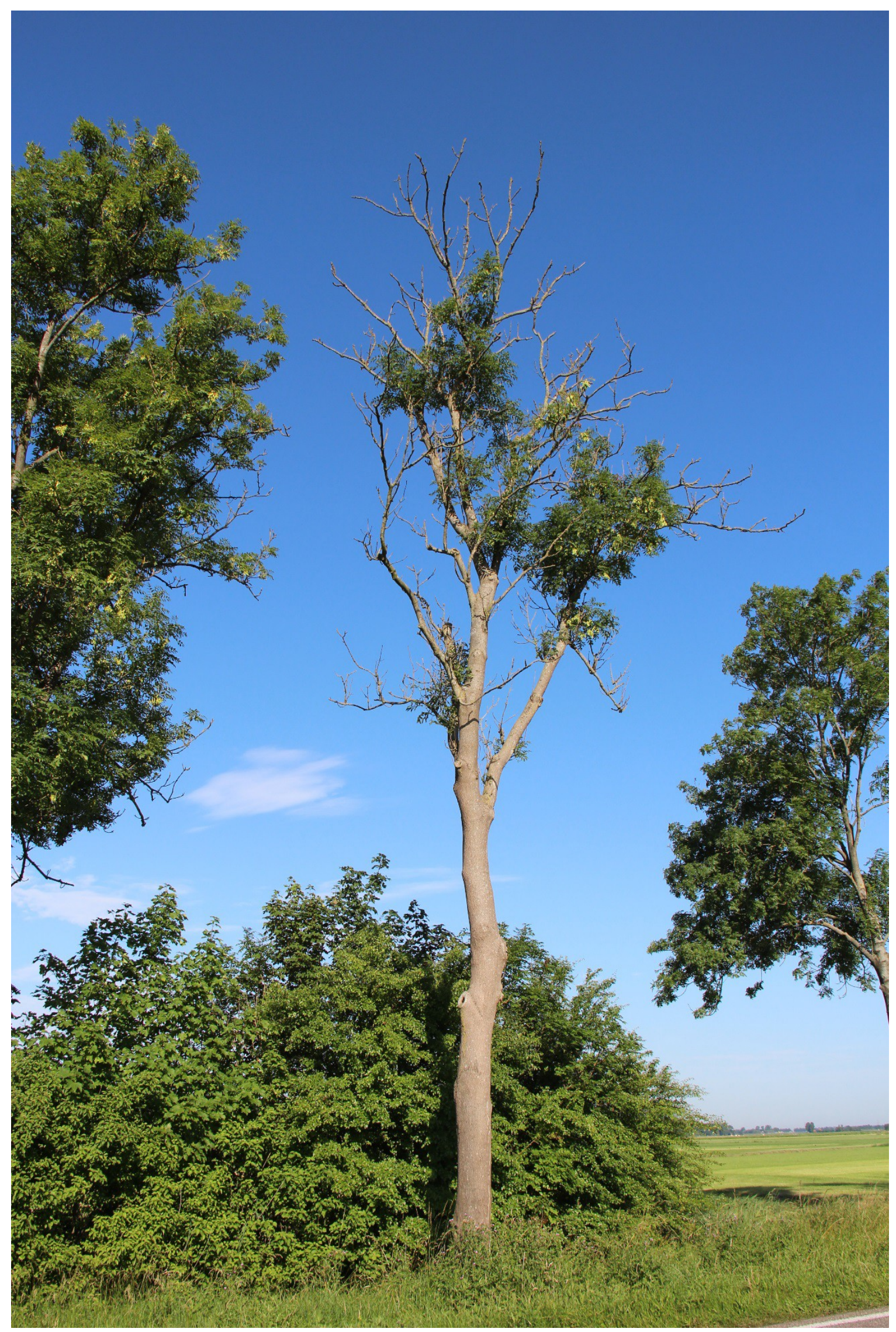

Foto $6 a$. Bladverlies $81-99 \%$, index 5 


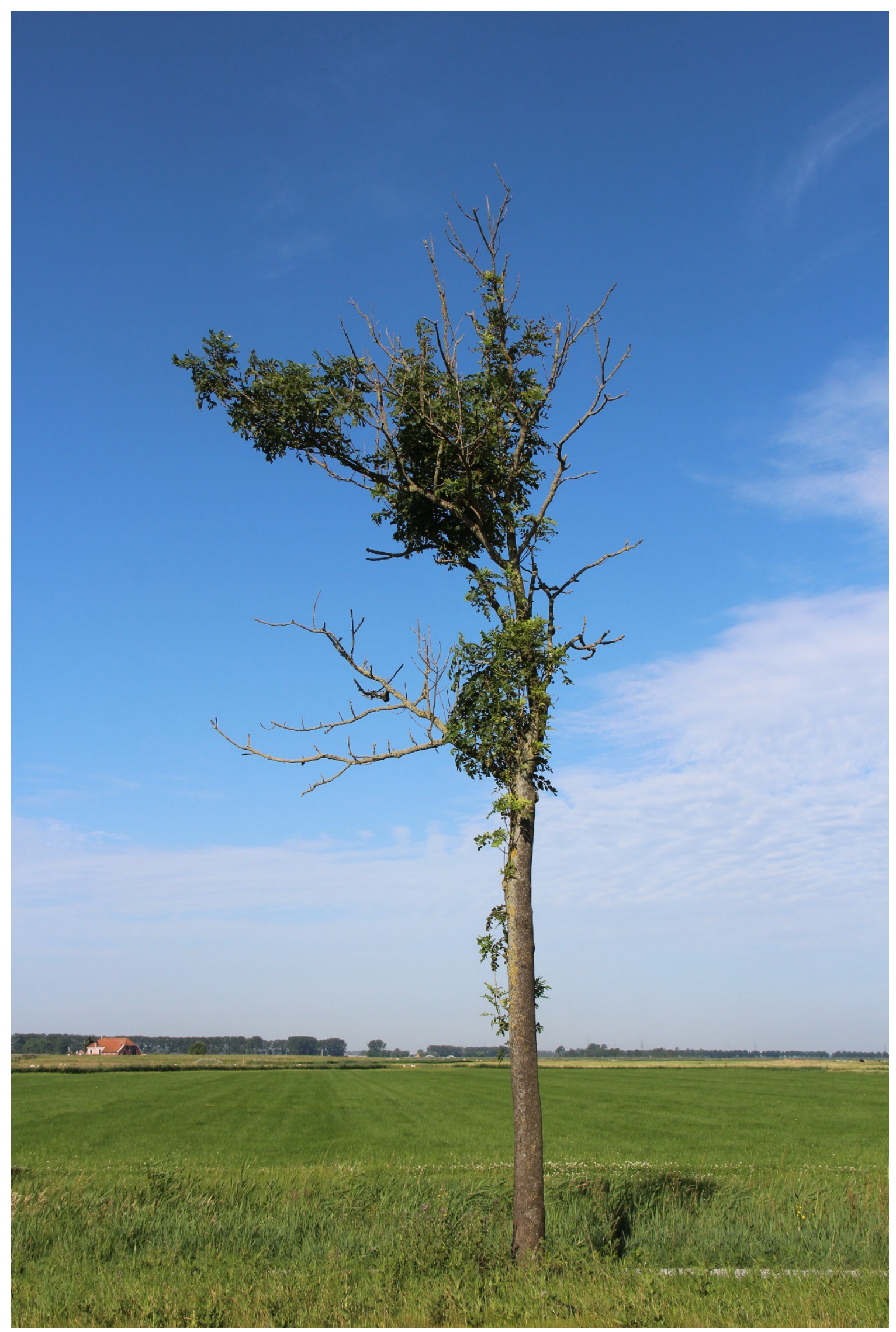

Foto $6 \mathrm{~b}$. Bladverlies $81-99 \%$, index 5 


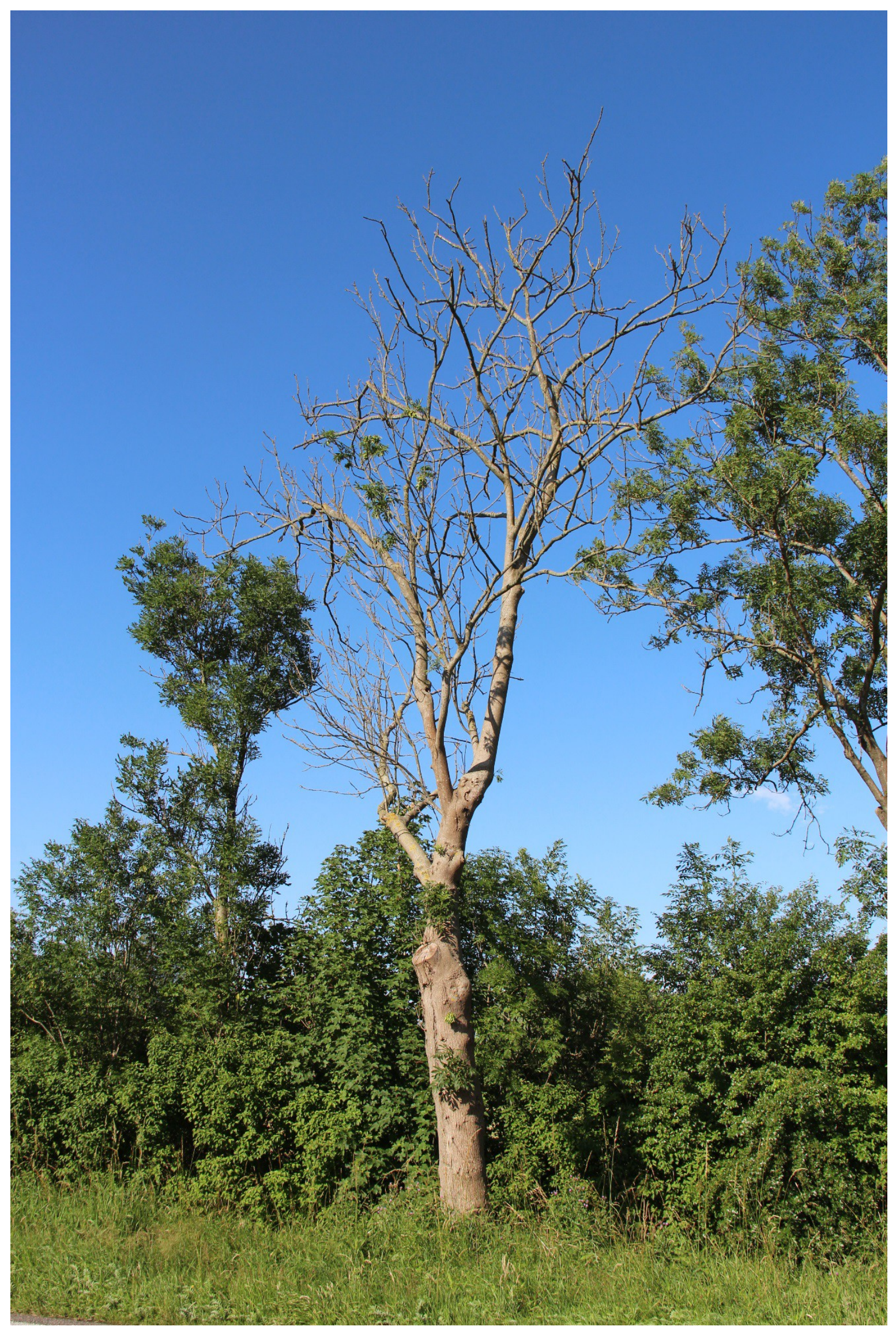

Foto 7 a. Bladverlies $100 \%$, index 6 


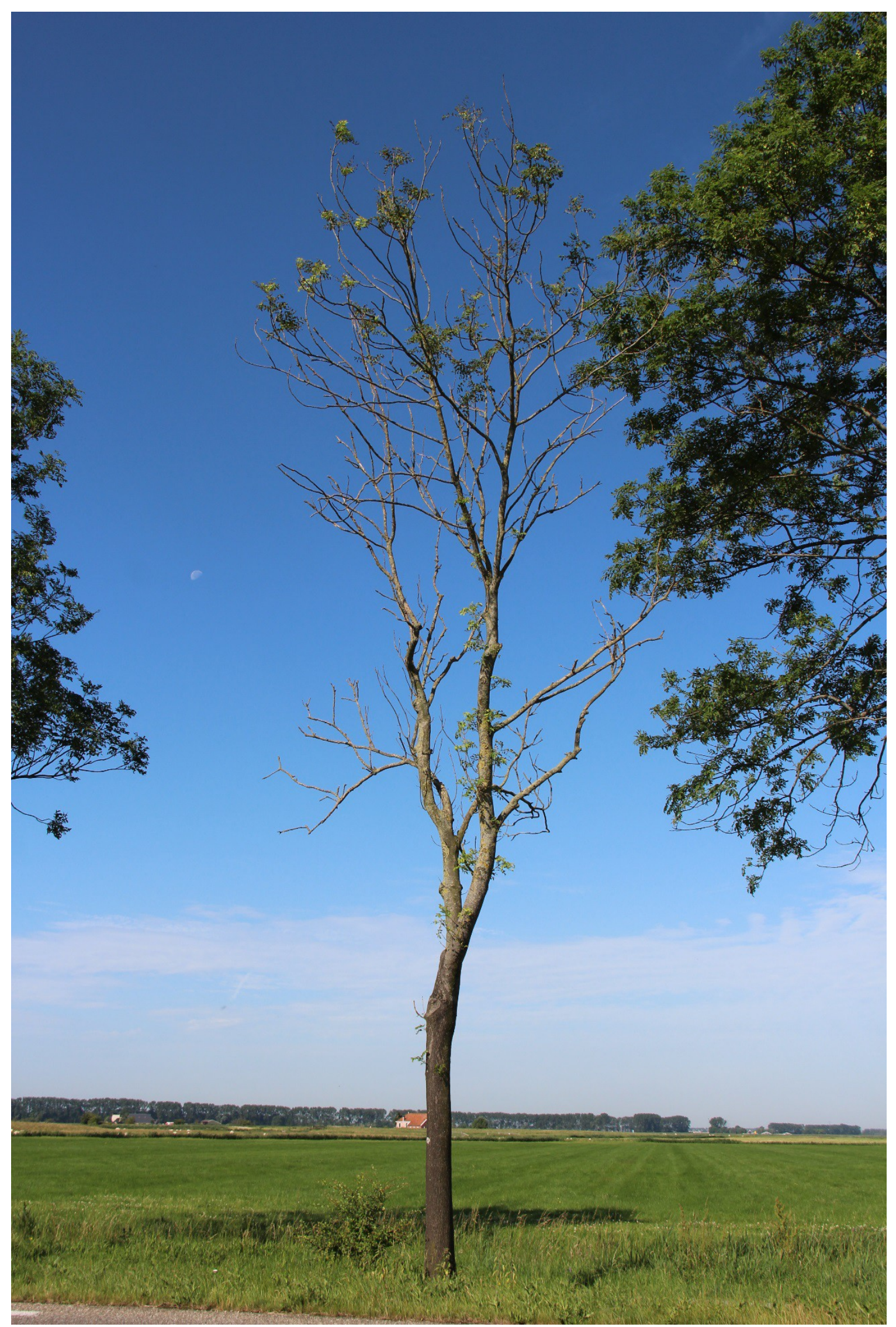

Foto $7 b$. Bladverlies $100 \%$, index 6 
Tabel 5. Percentage blad door waterlotvorming.

\begin{tabular}{|c|c|c|}
\hline Klasse & $\begin{array}{c}\text { Percentage nieuw blad ten gevolge van } \\
\text { waterlotvorming }\end{array}$ & $\begin{array}{c}\text { Corresponderend } \\
\text { afbeeldingsnummer }\end{array}$ \\
\hline 0 & $0 \%$ (geen symptomen) & 1 \\
\hline 1 & $<5 \%$ & 8 \\
\hline 2 & $5-20 \%$ & 10 \\
\hline 3 & $21-50 \%$ & 11 \\
\hline 4 & $51-80 \%$ & 12 \\
\hline 5 & $81-99 \%$ & 13 \\
\hline 6 & $100 \%$ & 9 \\
\hline
\end{tabular}


Van iedere klasse bladpercentage ten gevolge van waterlotvorming worden 2 foto's getoond a en b. Foto's genomen door Henry Kuppen, Terra Nostra.

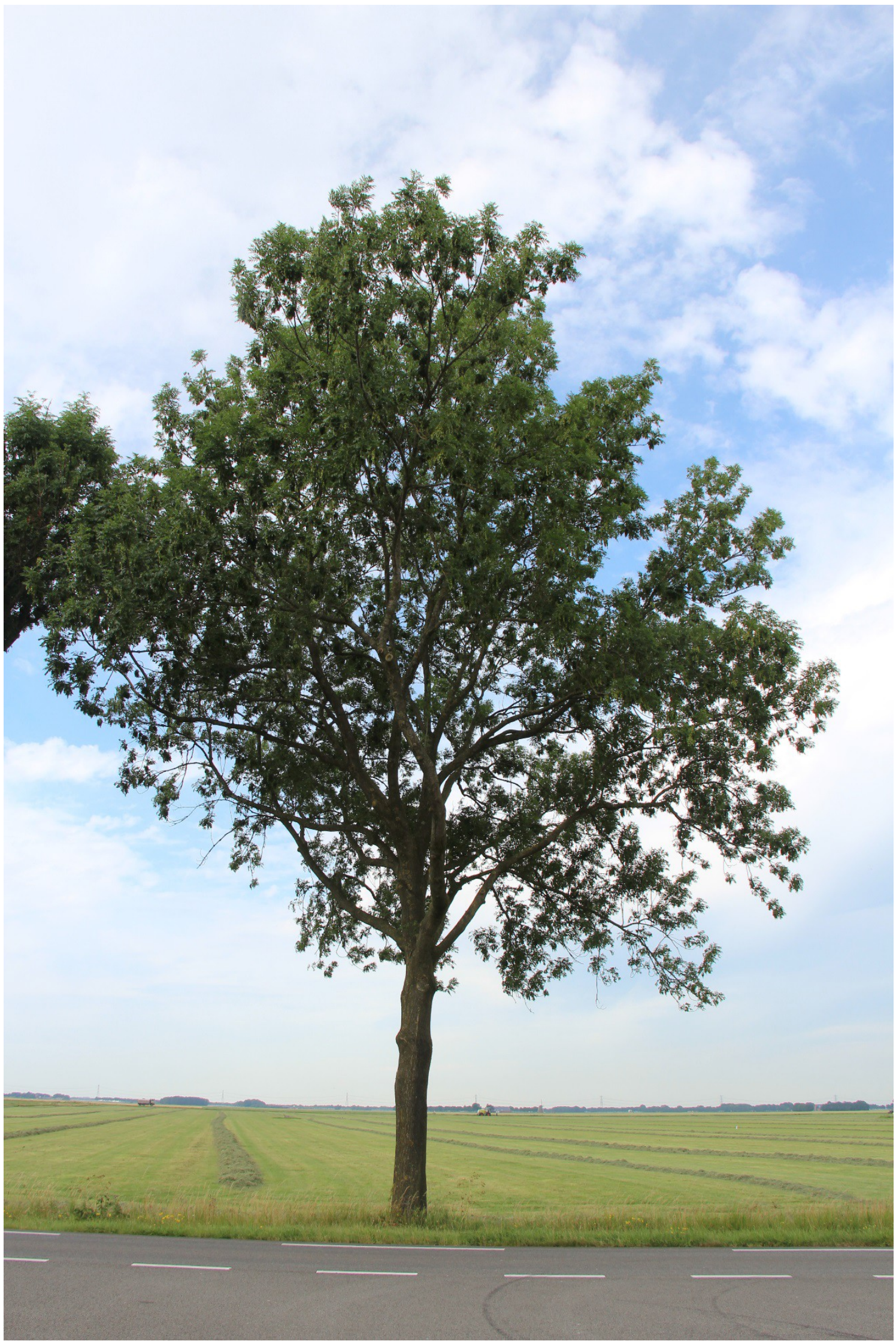


Foto 1a. Geen waterlotvoming, index 0

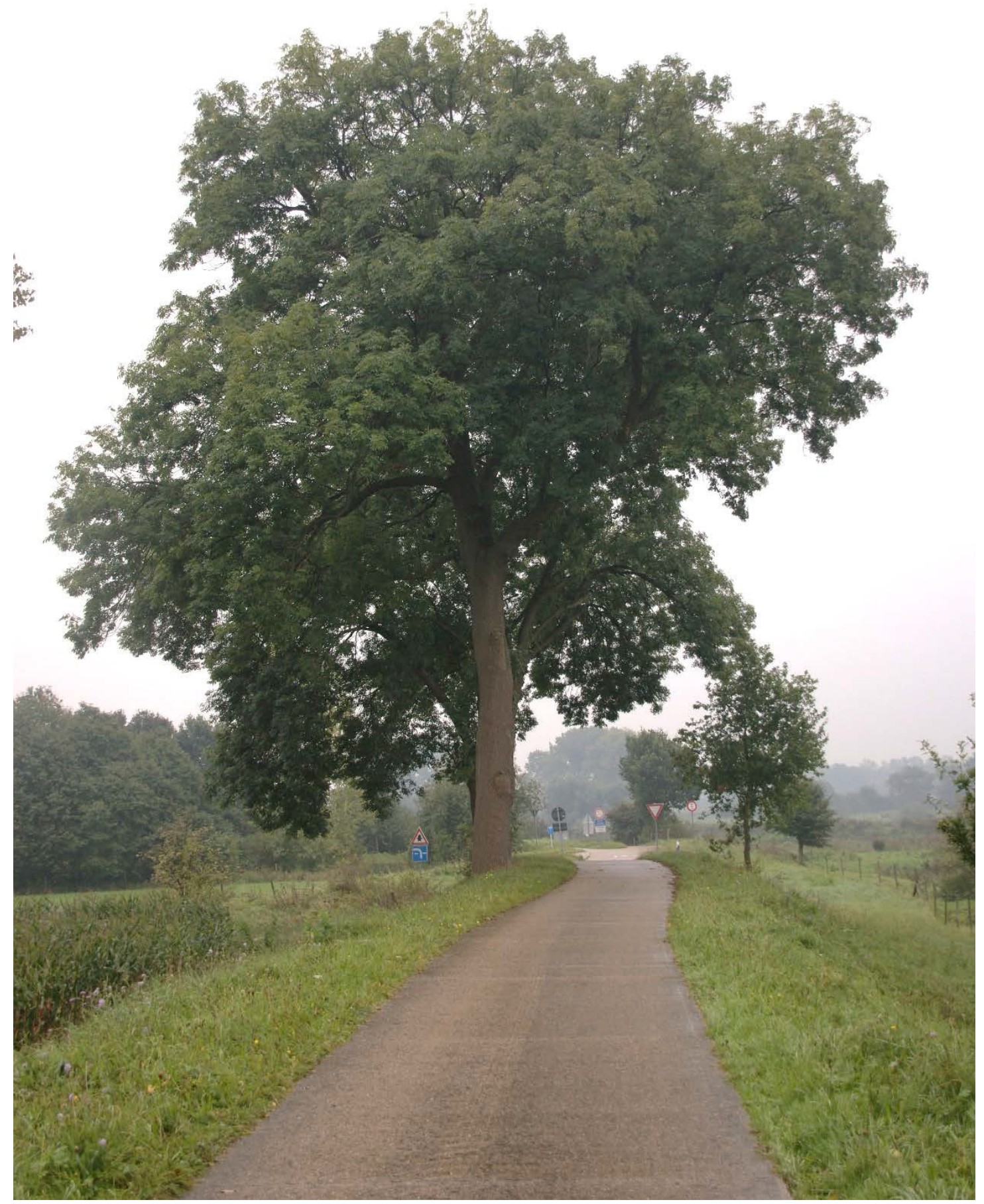

Foto 1 b. Geen waterlotvorming, index 0 


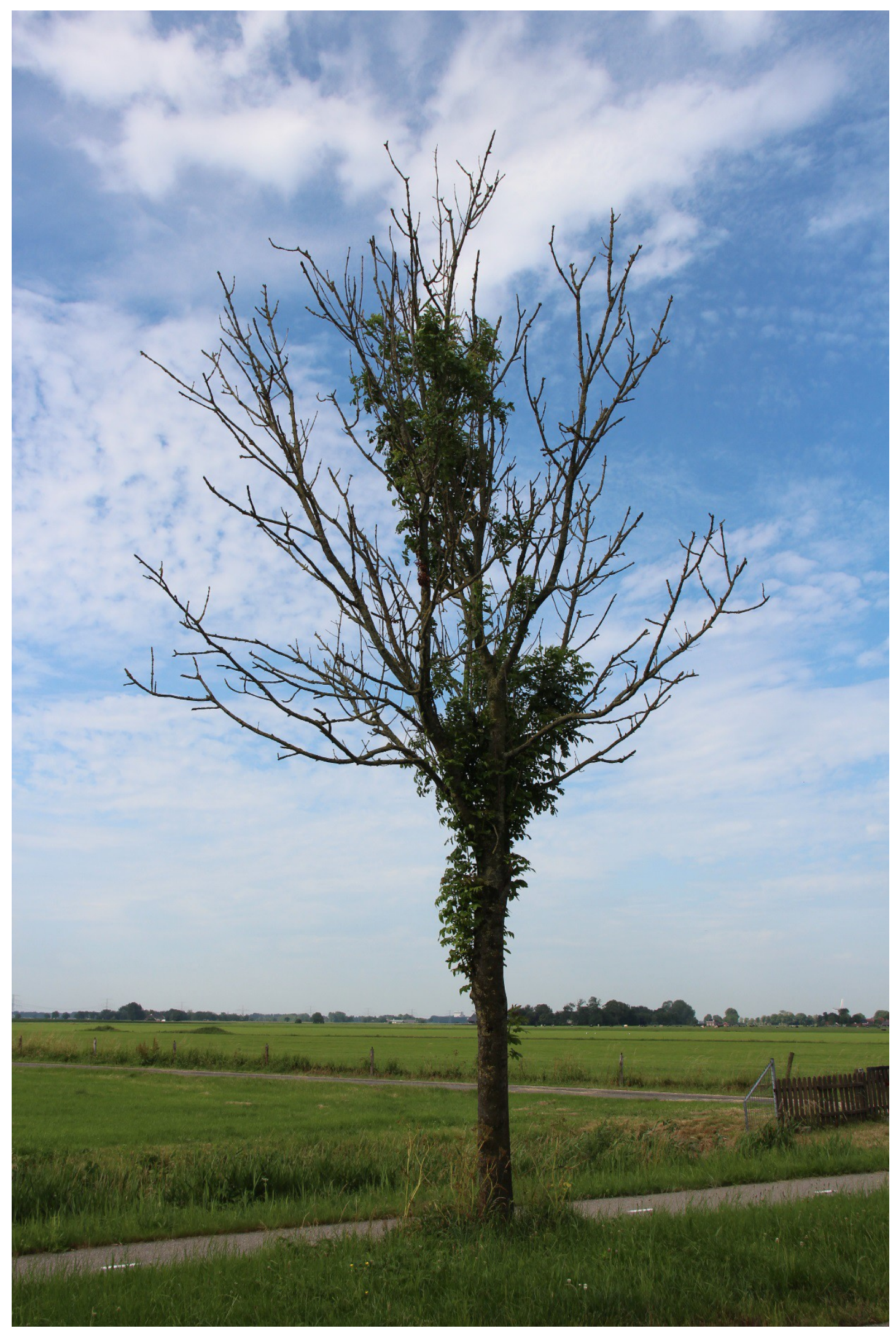

Foto 8 a. Bladpercentage door waterlotvorming is minder dan $5 \%$, index 1 


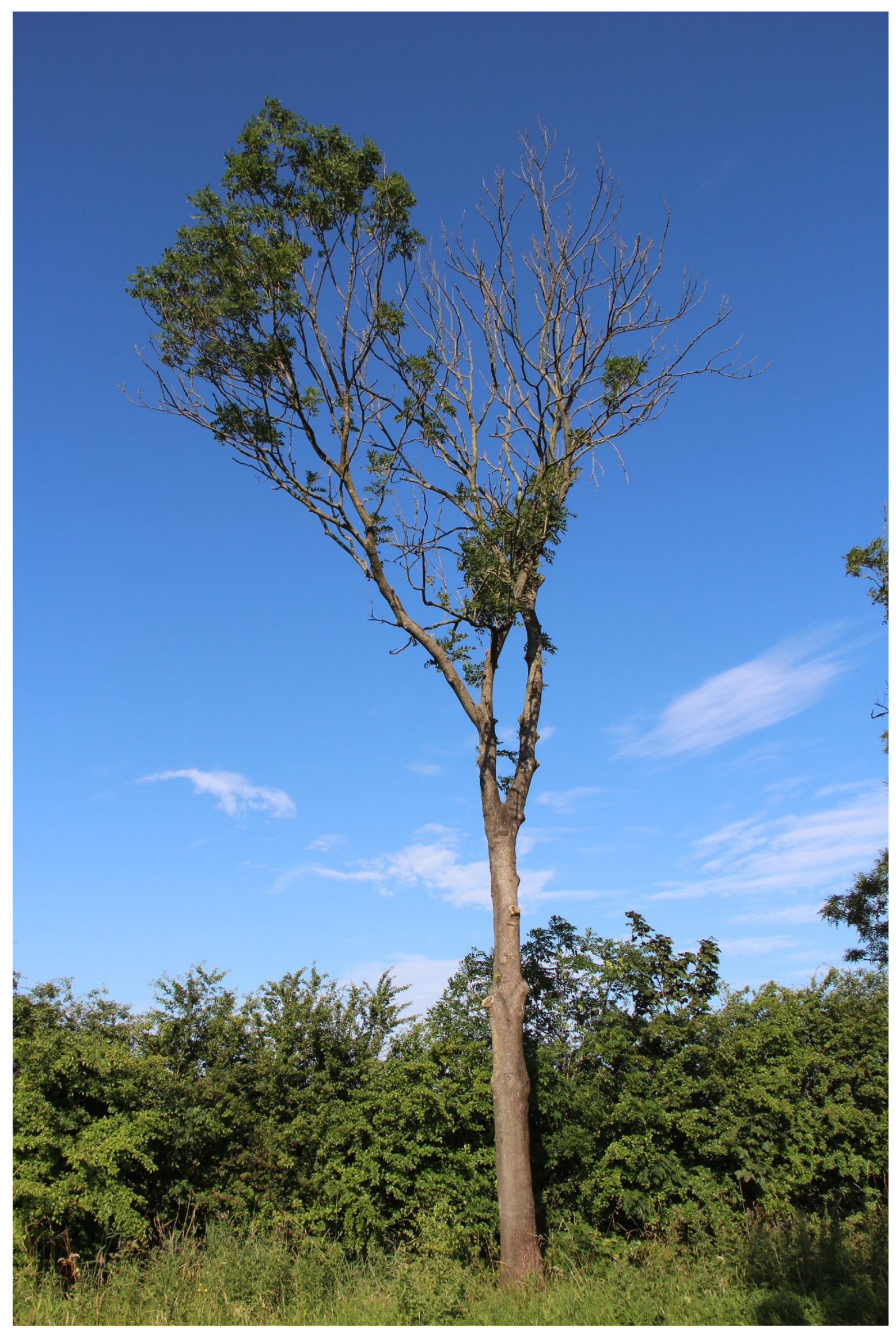

Foto 8 b. Bladpercentage door waterlotvorming is $<5 \%$, index 1 


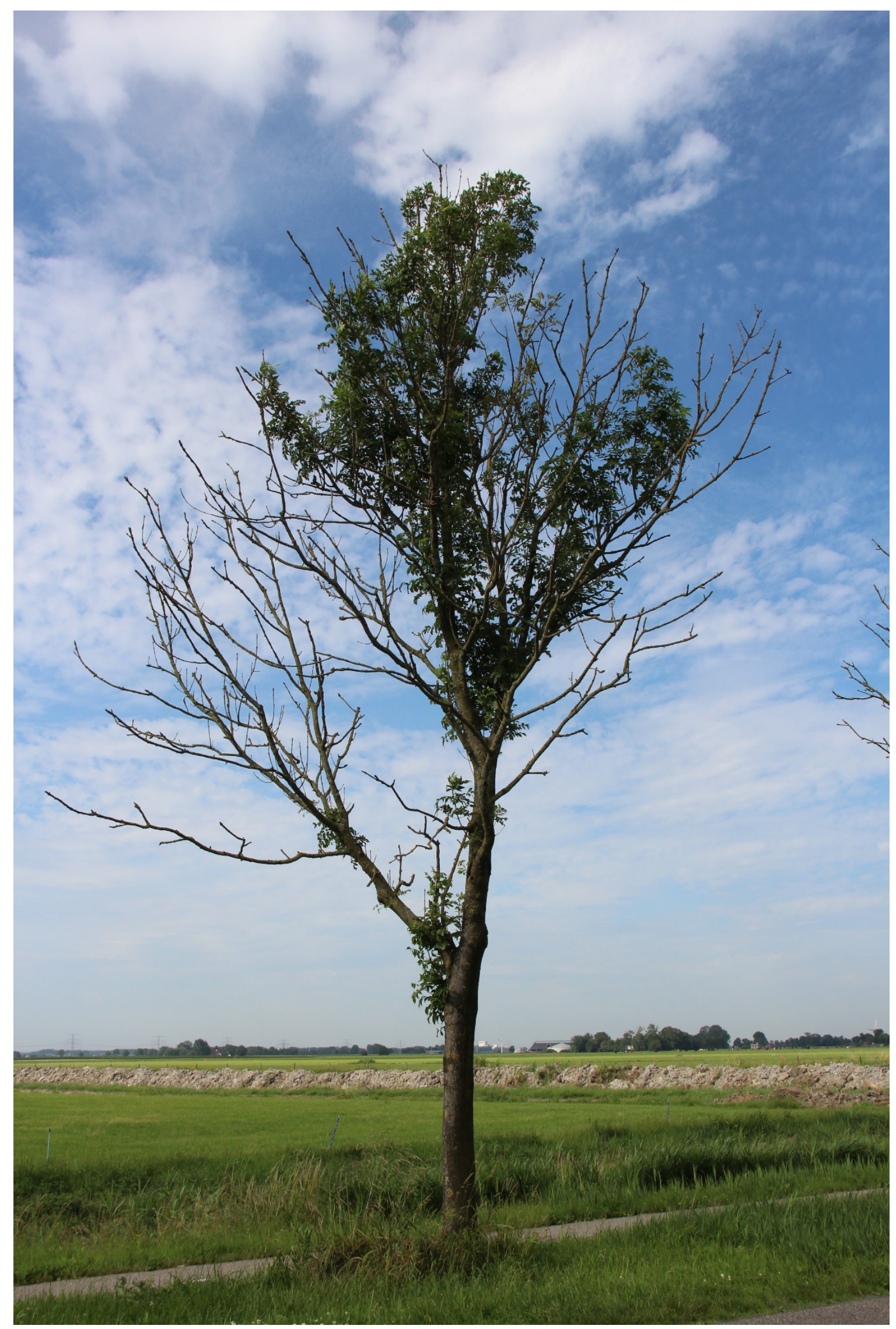

Foto 9a. Bladpercentage door waterlotvorming is $5-20 \%$, index 2 


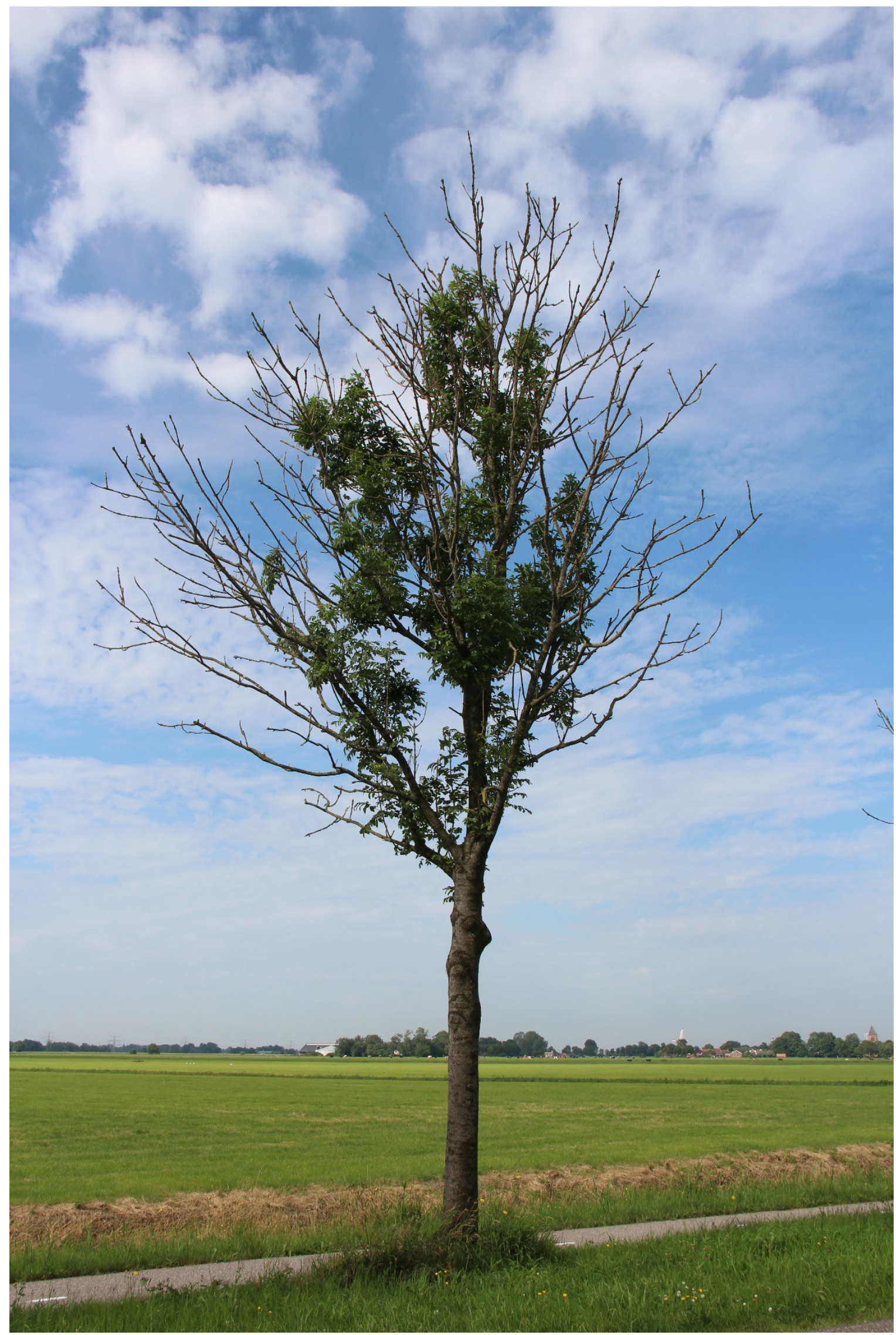

Foto $9 \mathrm{~b}$. Bladpercentage door waterlotvorming is $5-20 \%$, index 2 


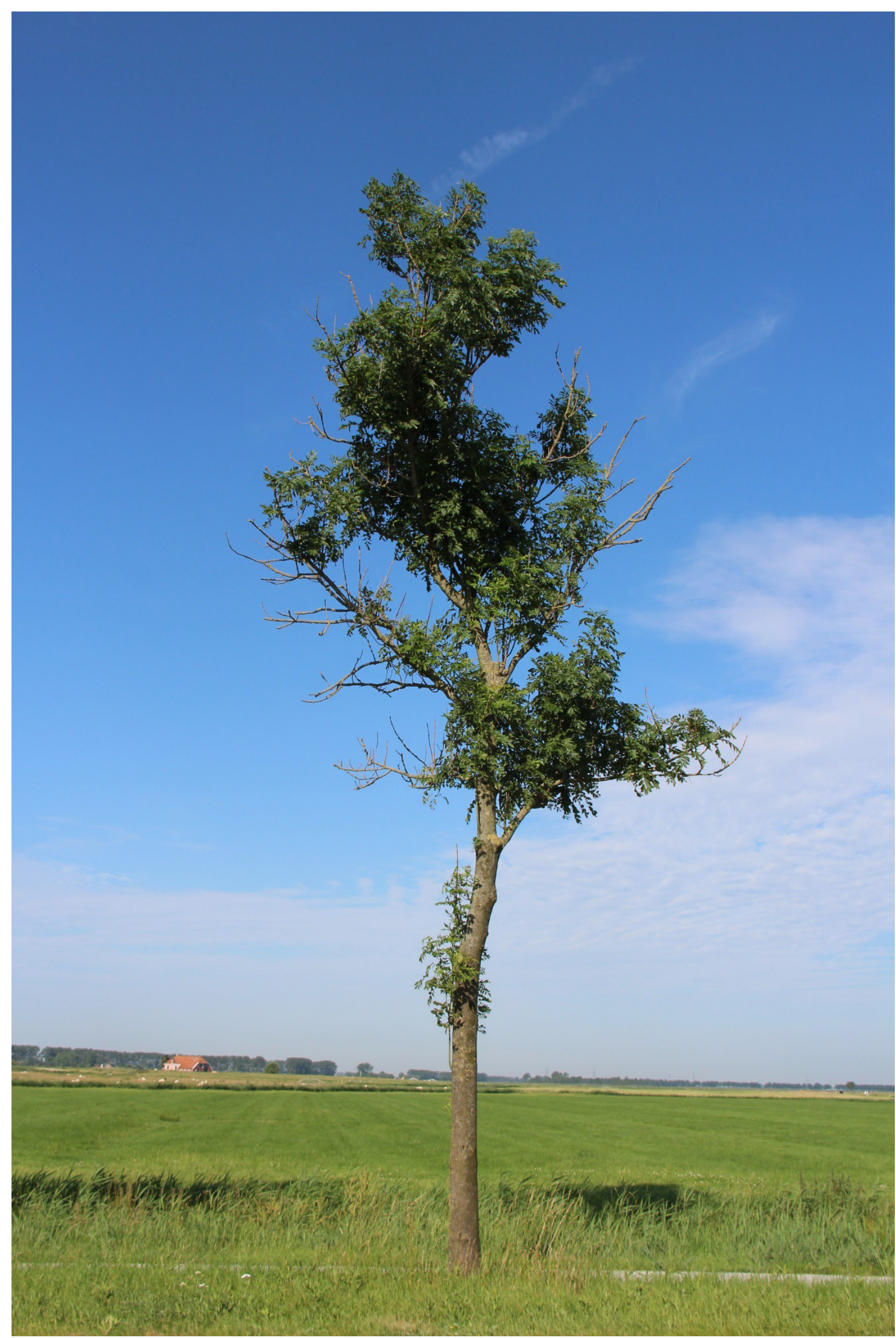

Foto 10 a. Bladpercentage door waterlotvorming is $21-50 \%$, index 3 


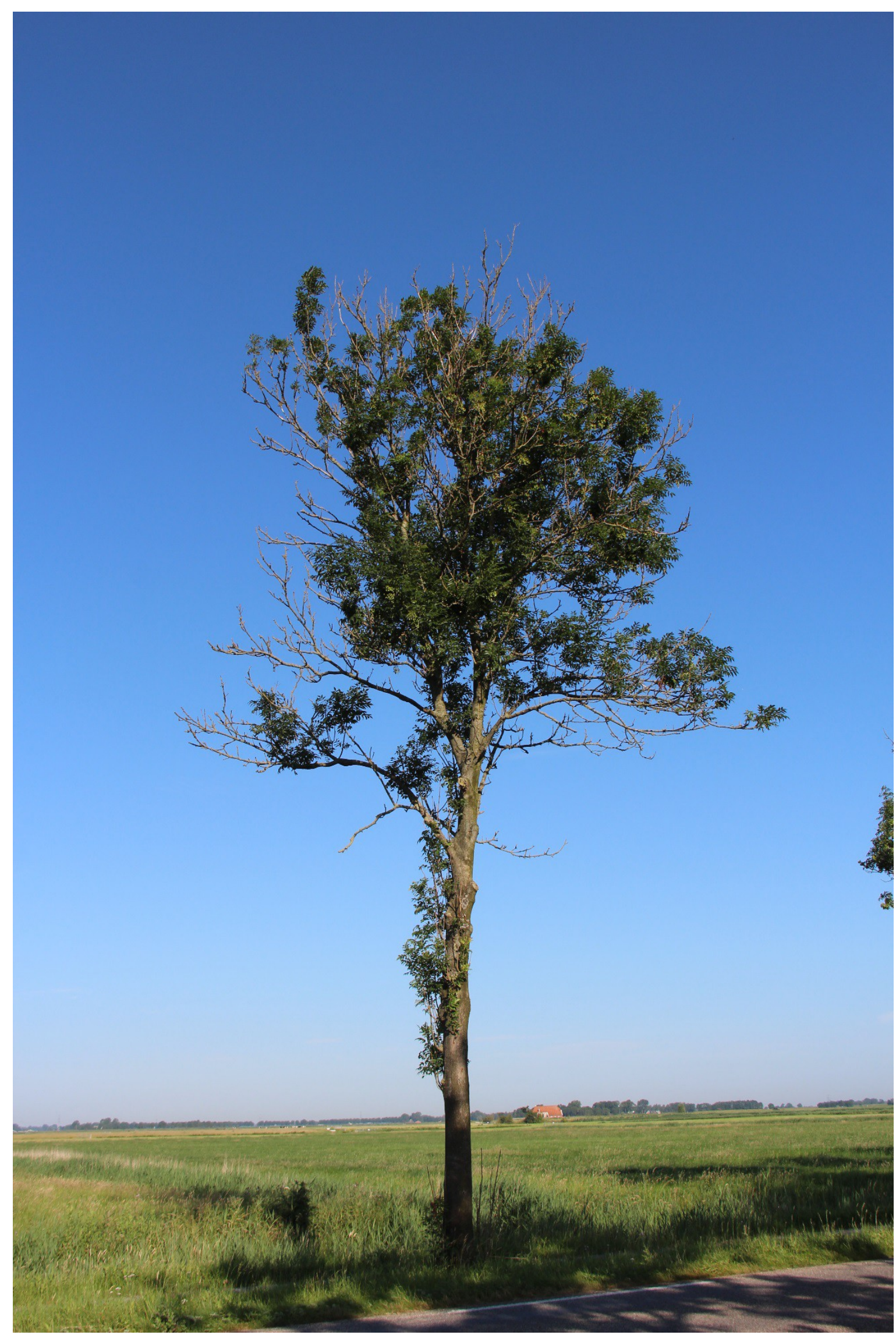

Foto $10 \mathrm{~b}$. Bladpercentage door waterlotvorming is $21-50 \%$, index 3 


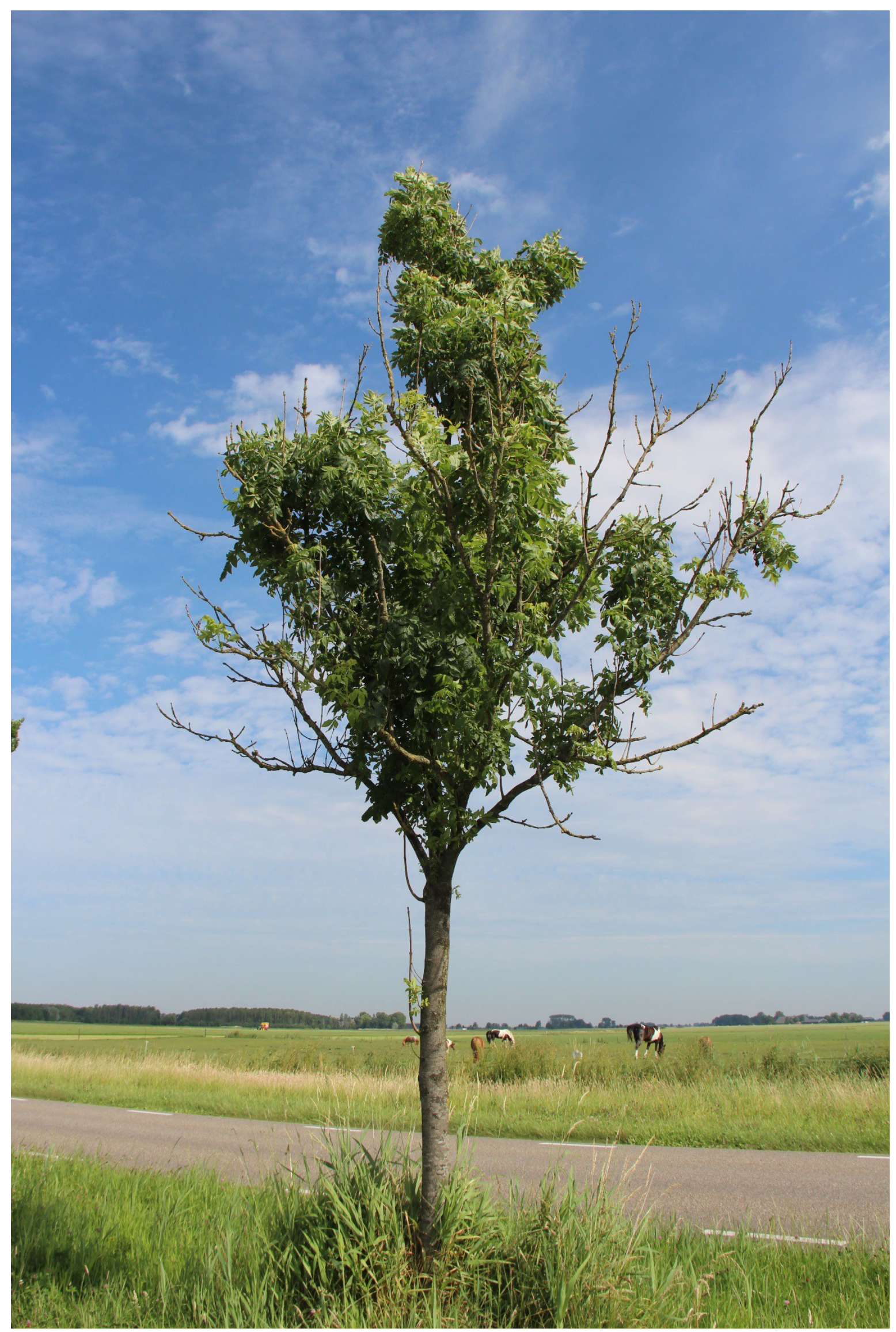

Foto 11 a. Bladpercentage door waterlotvorming is $51-80 \%$, index 4 


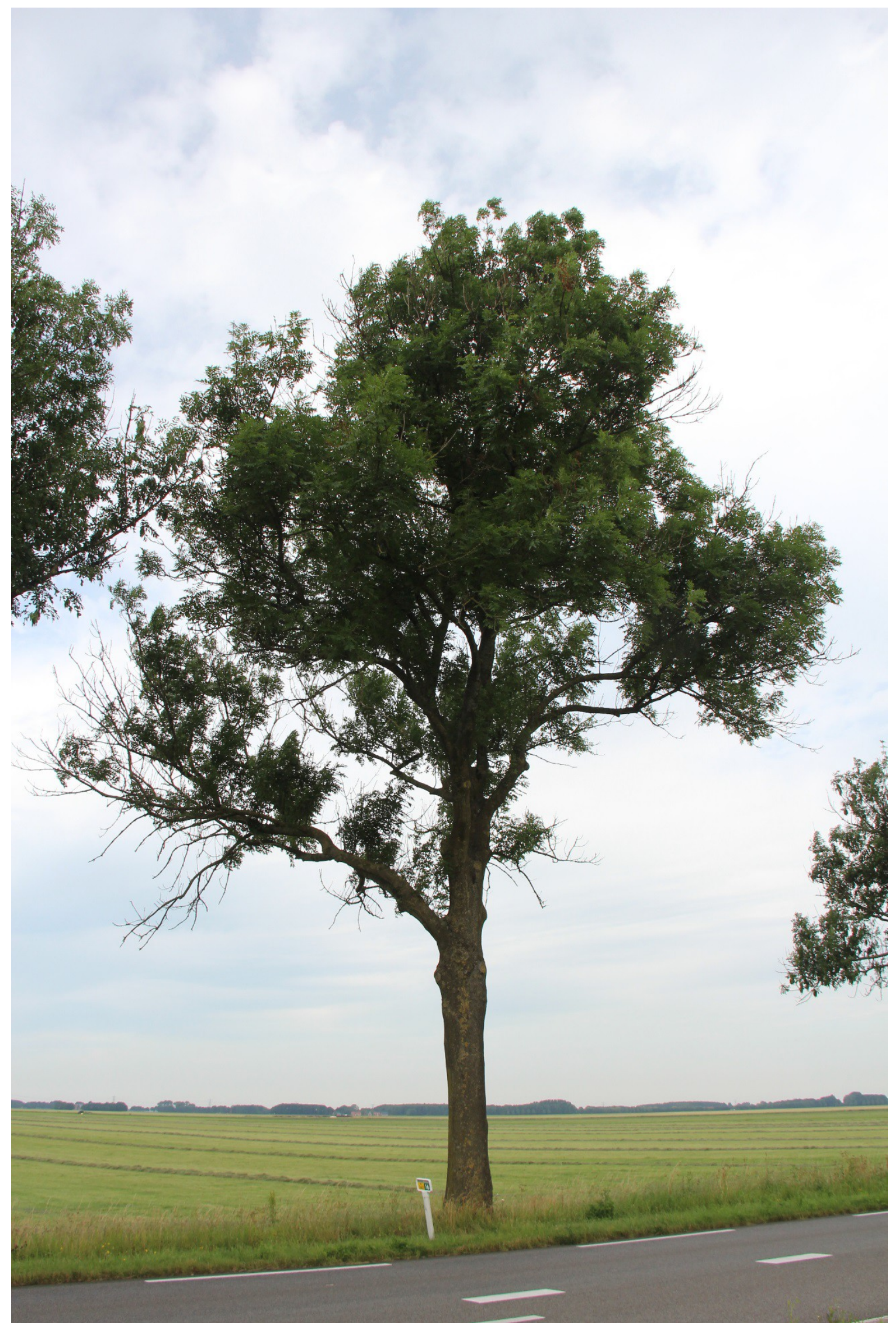

Foto 11 b. Bladpercentage door waterlotvorming is $51-80 \%$, index 4 


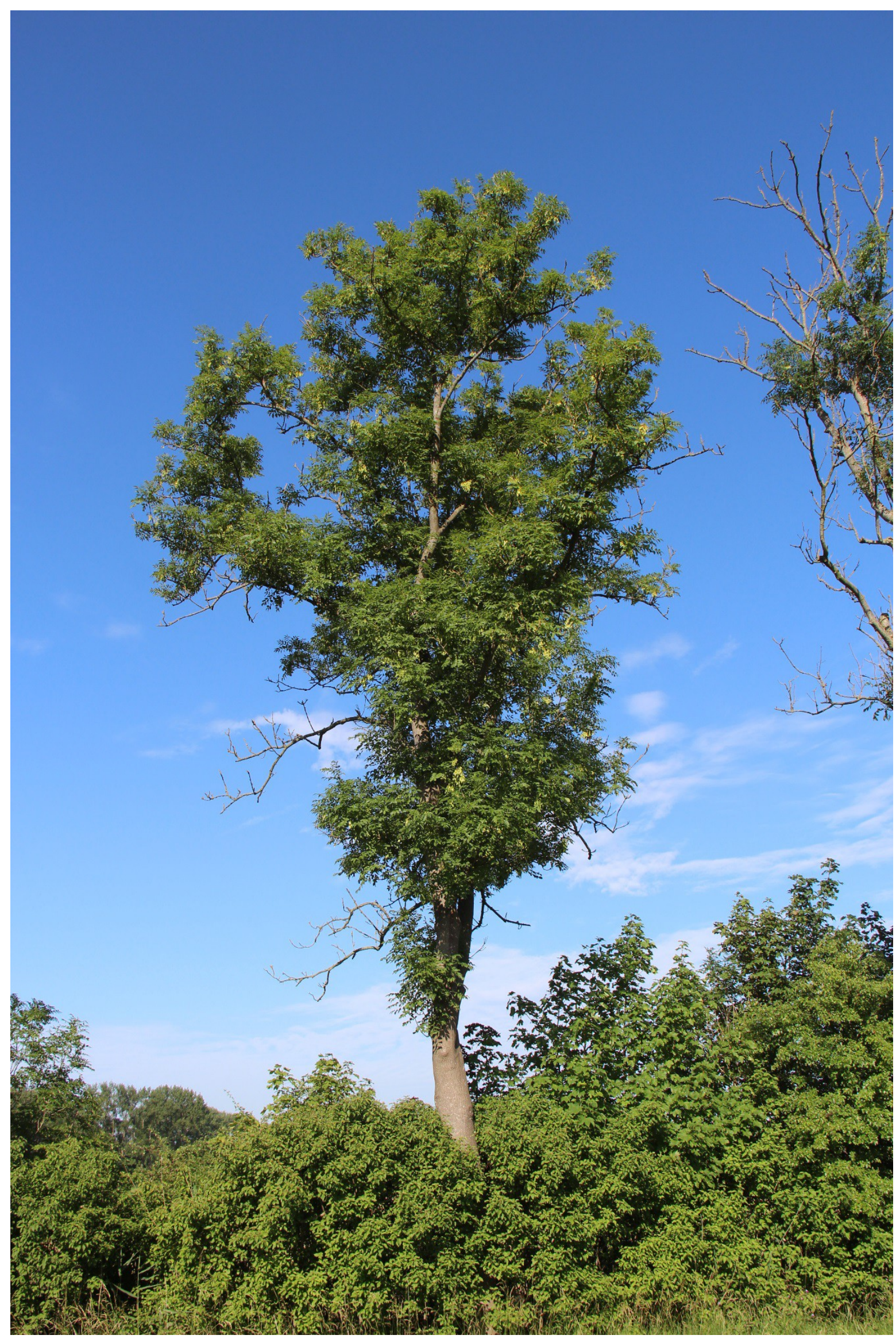

Foto 12 a. Bladpercentage door waterlotvorming is $81-99 \%$, index 5 


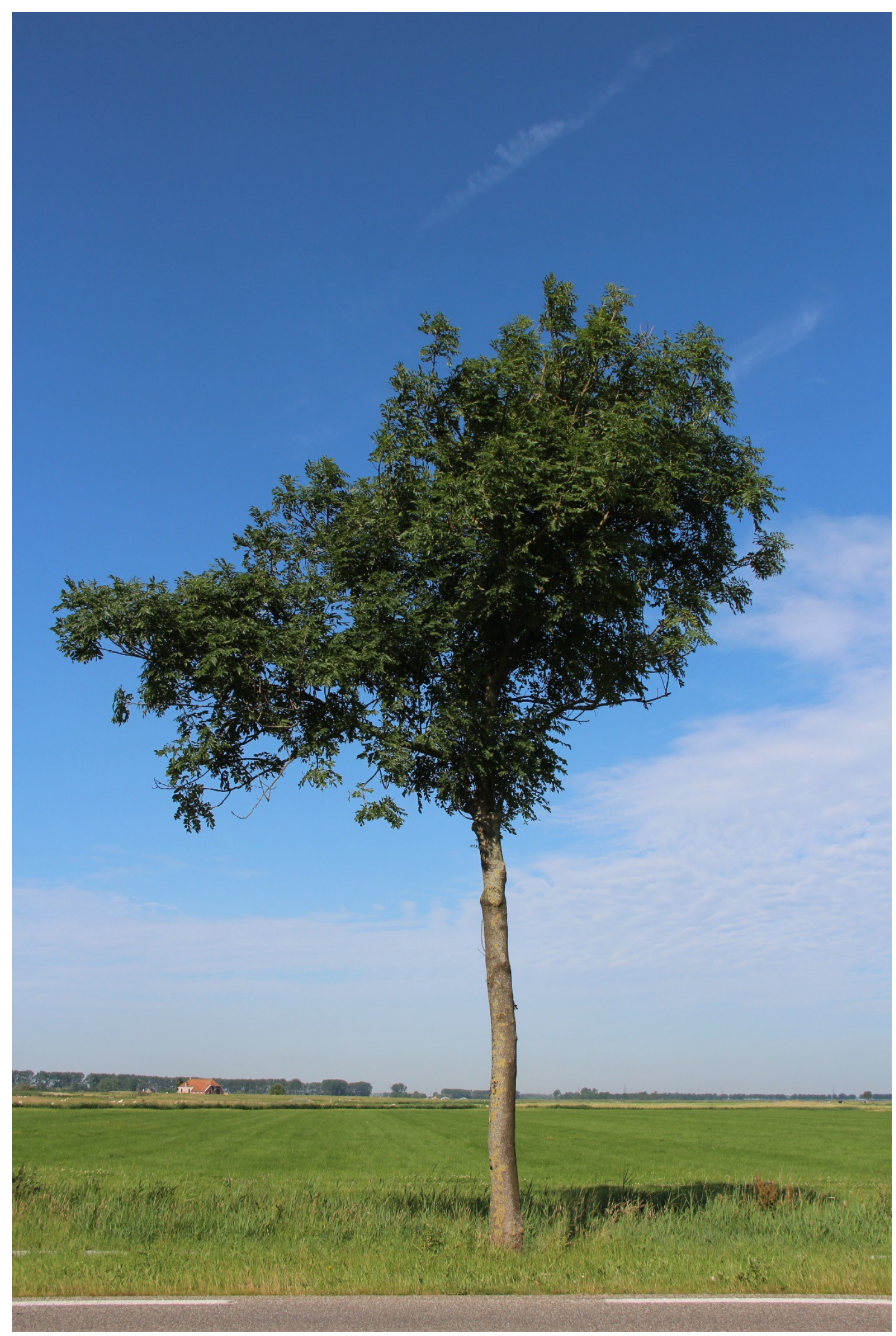

Foto 12 b. Bladpercentage door waterlotvorming is $81-99 \%$, index 5 


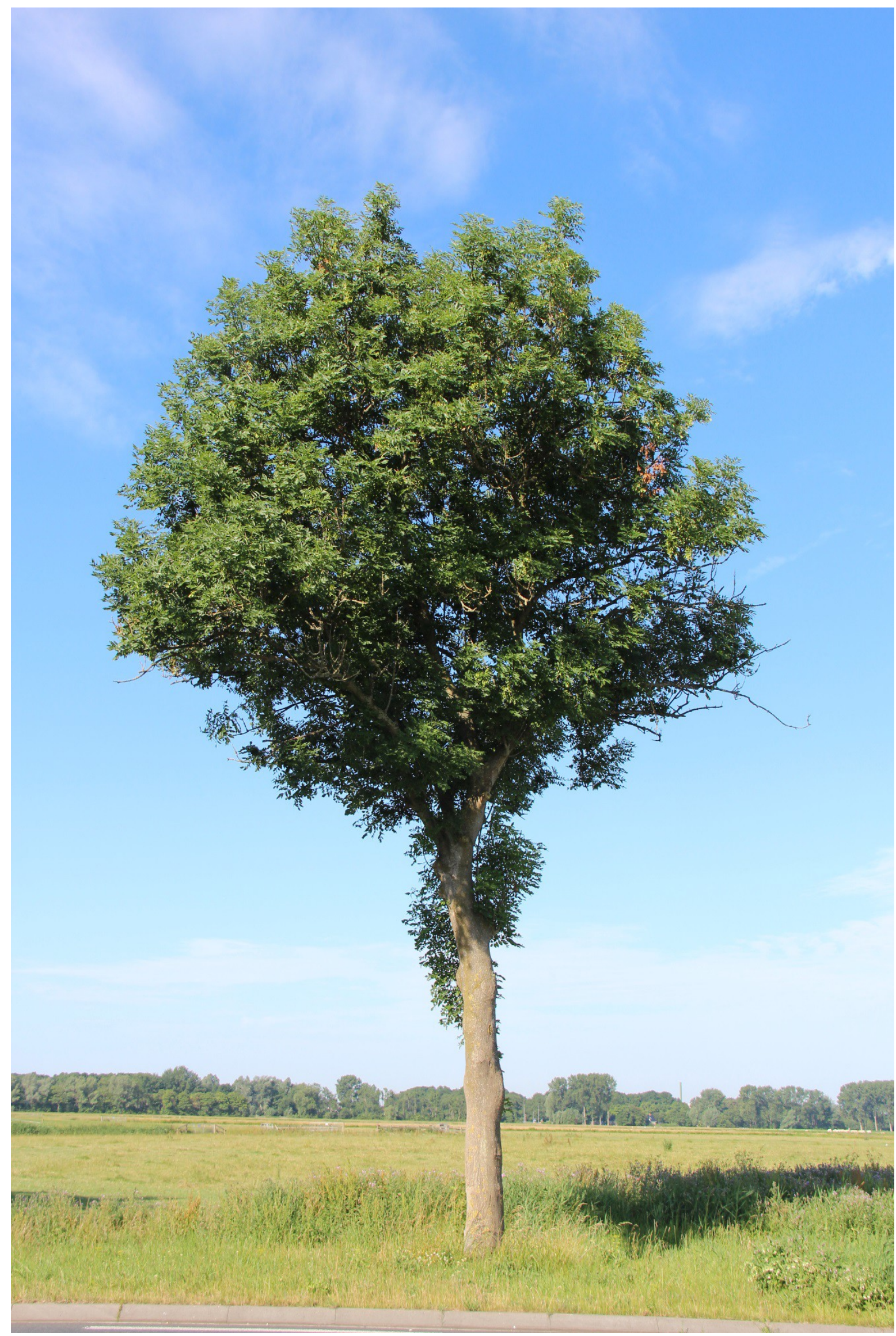

Foto 13 a. Bladpercentage door waterlotvorming is $100 \%$, index 6 


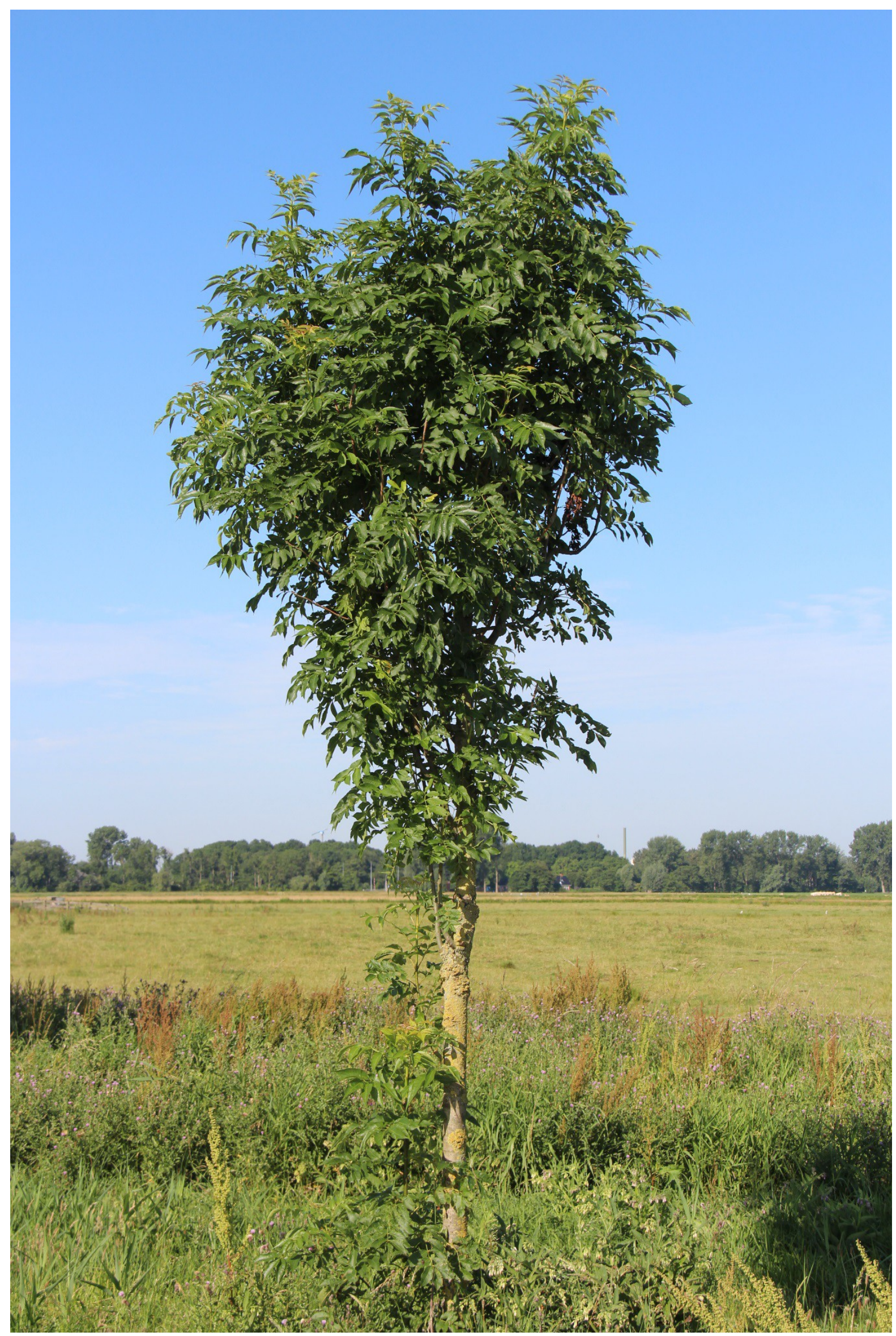

Foto $13 \mathrm{~b}$. Bladpercentage door waterlotvorming is $100 \%$, index 6 
Tabel 6. Ziekteklassen gebaseerd op de voortgang van ETS in individuele bomen.

\begin{tabular}{|c|c|c|c|c|}
\hline Ziekteklasse & Omschrijving & $\begin{array}{c}\text { Schematische } \\
\text { weergave }\end{array}$ & Beschrijving & $\begin{array}{l}\text { Corresponderend } \\
\text { afbeeldingsnummer }\end{array}$ \\
\hline 0 & $\begin{array}{c}\text { Geen } \\
\text { aantasting }\end{array}$ & & $\begin{array}{c}\text { Geen symptomen van } \\
\text { aantasting door ETS } \\
\text { zichtbaar. }\end{array}$ & 1 \\
\hline 1 & $\begin{array}{c}\text { Licht } \\
\text { aangetast }\end{array}$ & & $\begin{array}{c}\text { Beperkte symptomen op } \\
\text { één of enkele scheuten: } \\
\text { bruin, verwelkt of } \\
\text { verdroogd blad en/of } \\
\text { enkele } \\
\text { aantastingsplekken op } \\
\text { twijgen of stam. }\end{array}$ & 14 \\
\hline 2 & $\begin{array}{c}\text { Matig } \\
\text { aangetast }\end{array}$ & & $\begin{array}{c}\text { Meerdere twijgen } \\
\text { afgestorven, afgestorven } \\
\text { aantastingsplekken op } \\
\text { takken en/of stam en } \\
\text { hergroei. }\end{array}$ & 15 \\
\hline 3 & $\begin{array}{c}\text { Zwaar } \\
\text { aangetast }\end{array}$ & & $\begin{array}{c}\text { Groot deel van de } \\
\text { scheuten en eventueel } \\
\text { ook deel van stam } \\
\text { afgestorven; meerdere } \\
\text { afgestorven } \\
\text { aantastingsplekken op de } \\
\text { stam en hergroei vanuit } \\
\text { de stambasis. }\end{array}$ & 16 \\
\hline 4 & Dood & & $\begin{array}{l}\text { Boom geheel } \\
\text { afgestorven. }\end{array}$ & 17 \\
\hline
\end{tabular}


Van iedere ziekteklasse worden 2 foto's getoond a en b. Foto's genomen door Henry Kuppen, Terra Nostra.

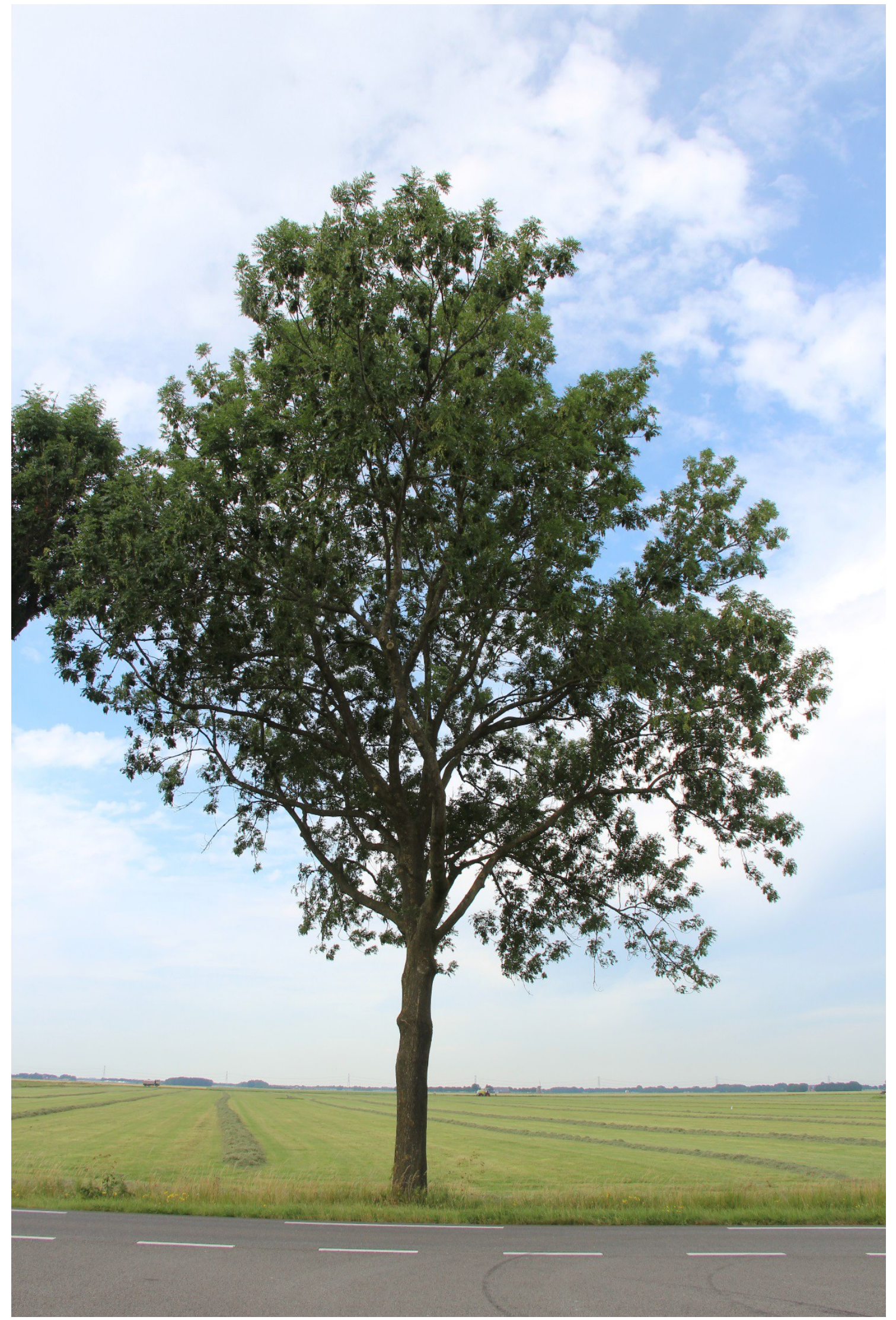

Foto 1a. Geen aantasting, ziekteklasse 0 


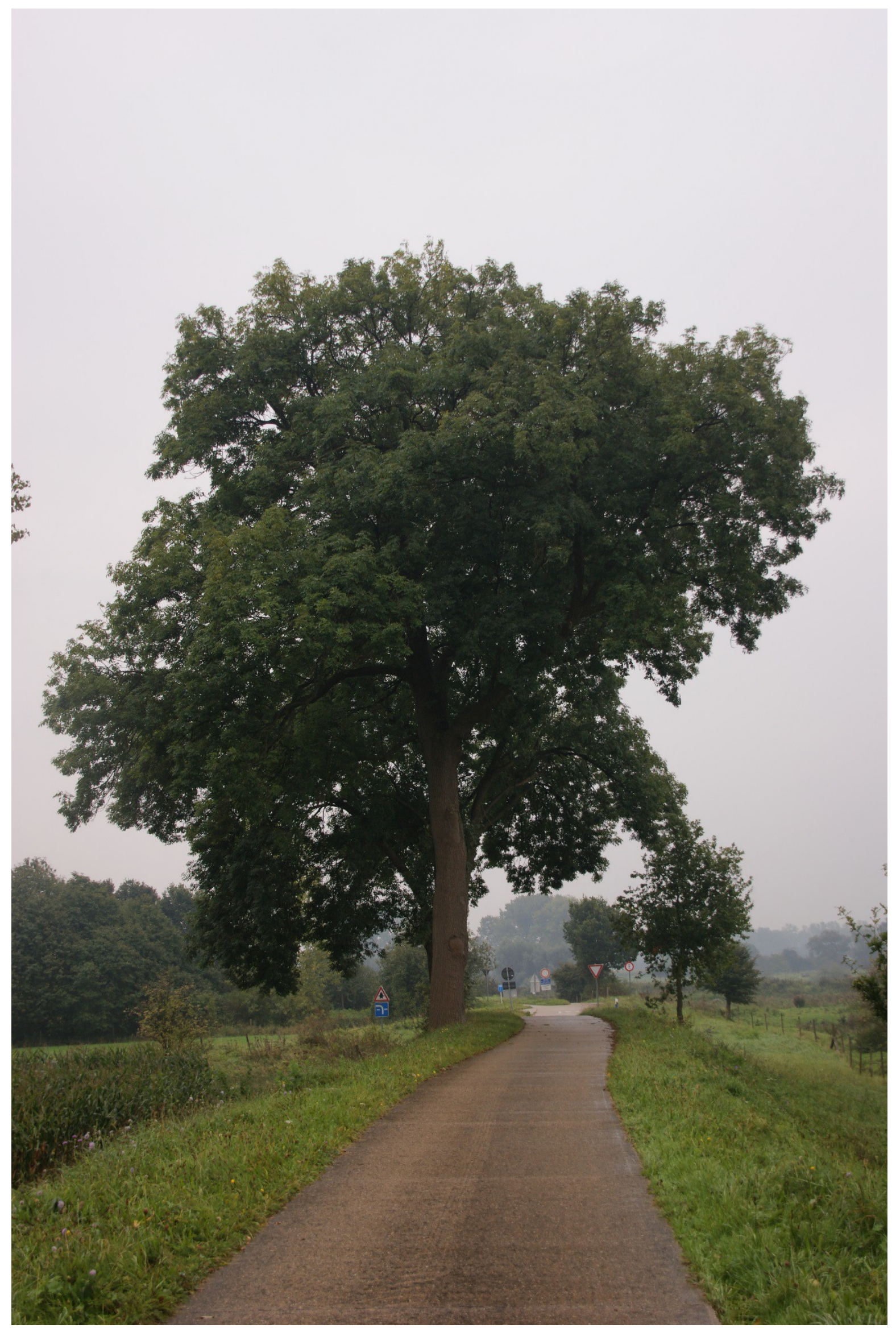

Foto 2 b. Geen aantasting, Ziekteklasse 0 


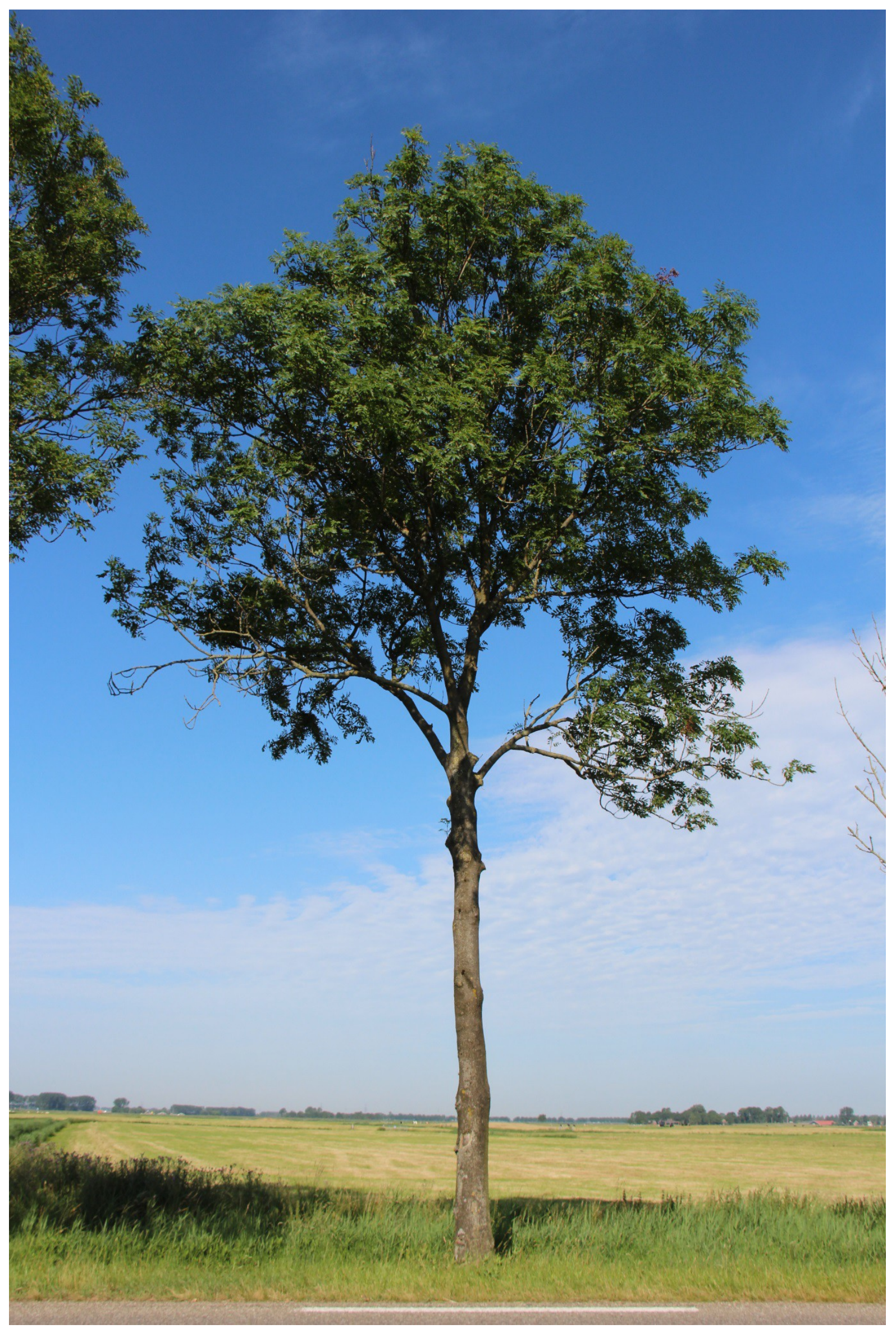

Foto 14a. Lichte aantasting, ziekteklasse 1 


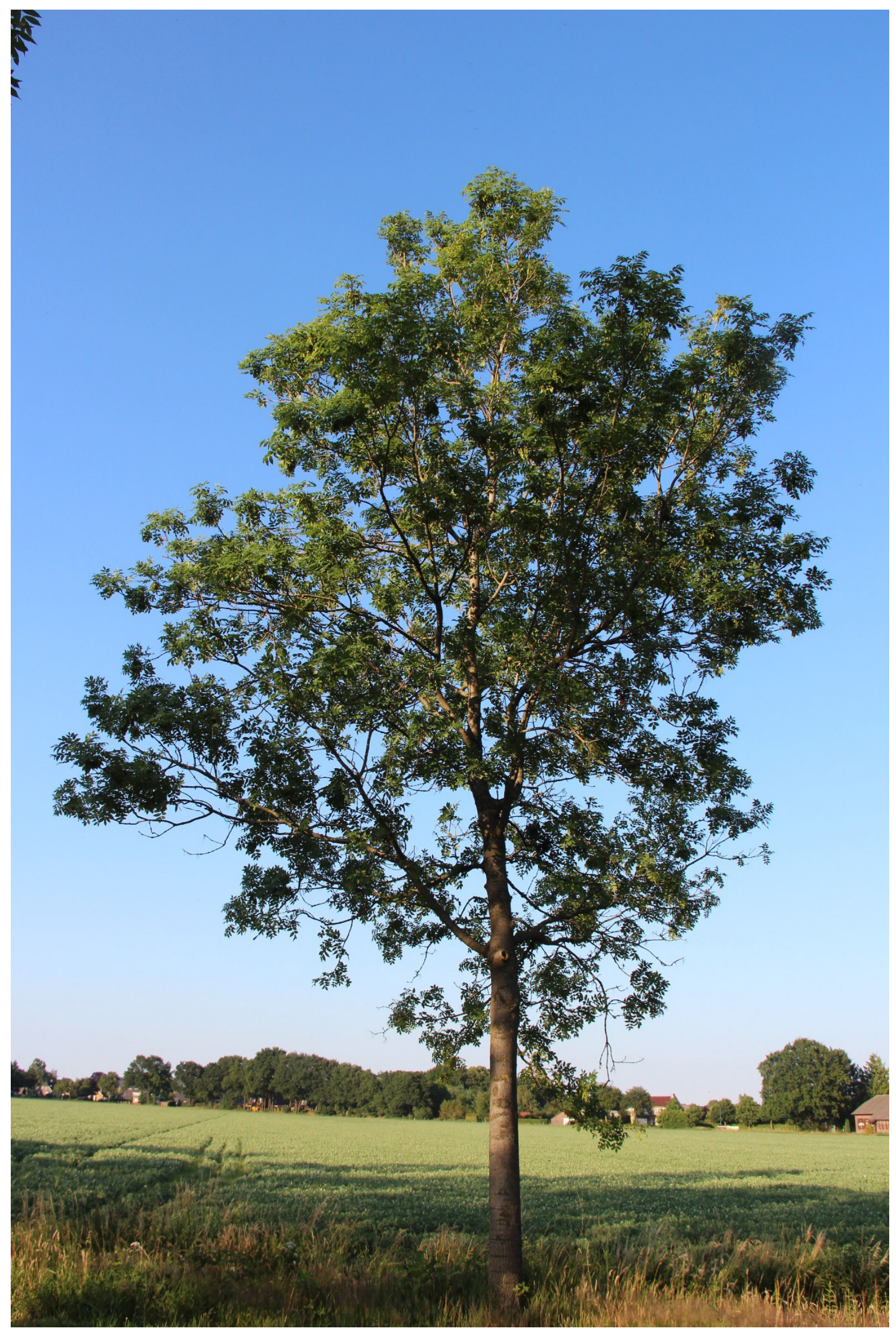

Foto $14 \mathrm{~b}$. Lichte aantasting, ziekteklasse 1 


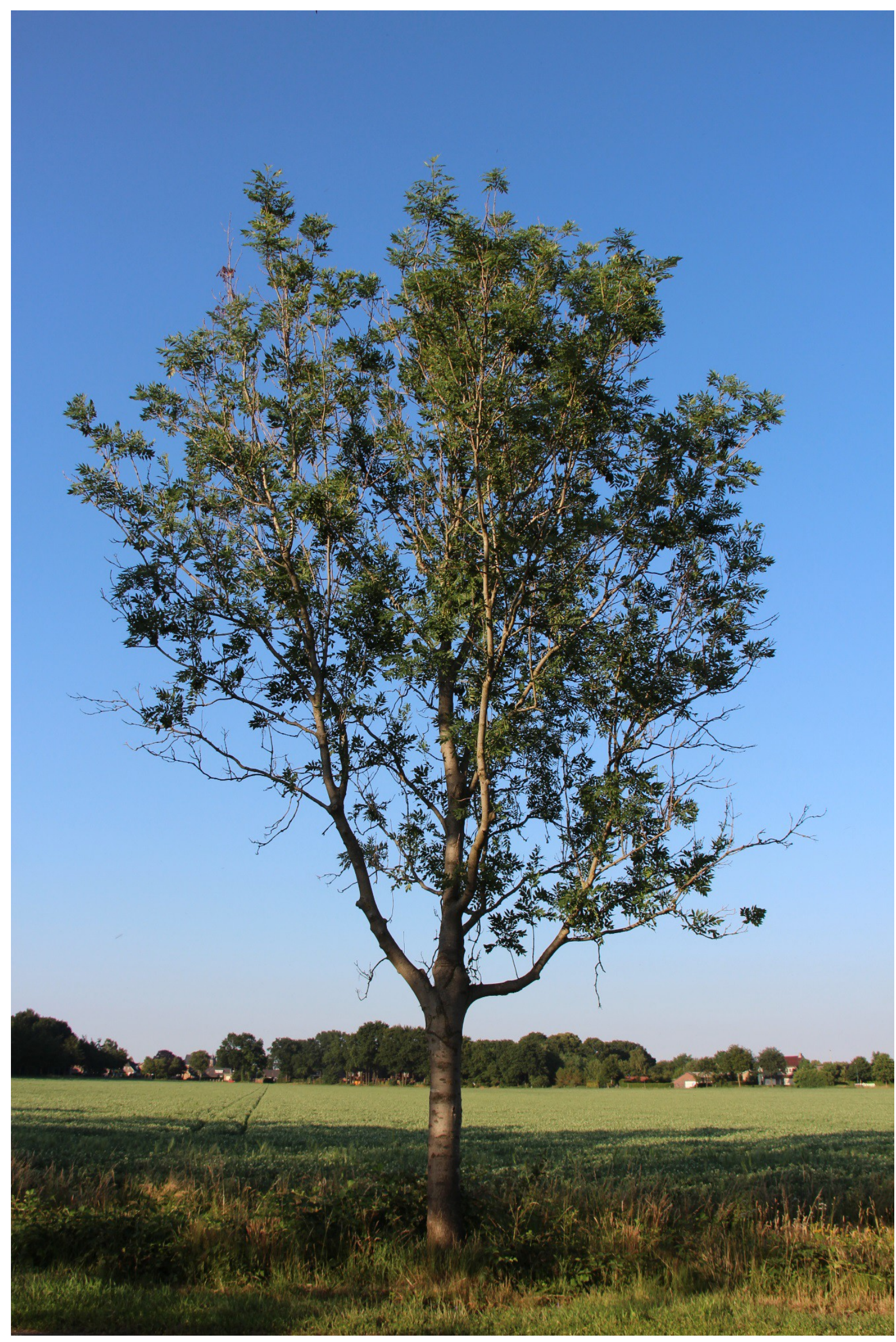

Foto 15 a. Matige aantasting, ziekteklasse 2 


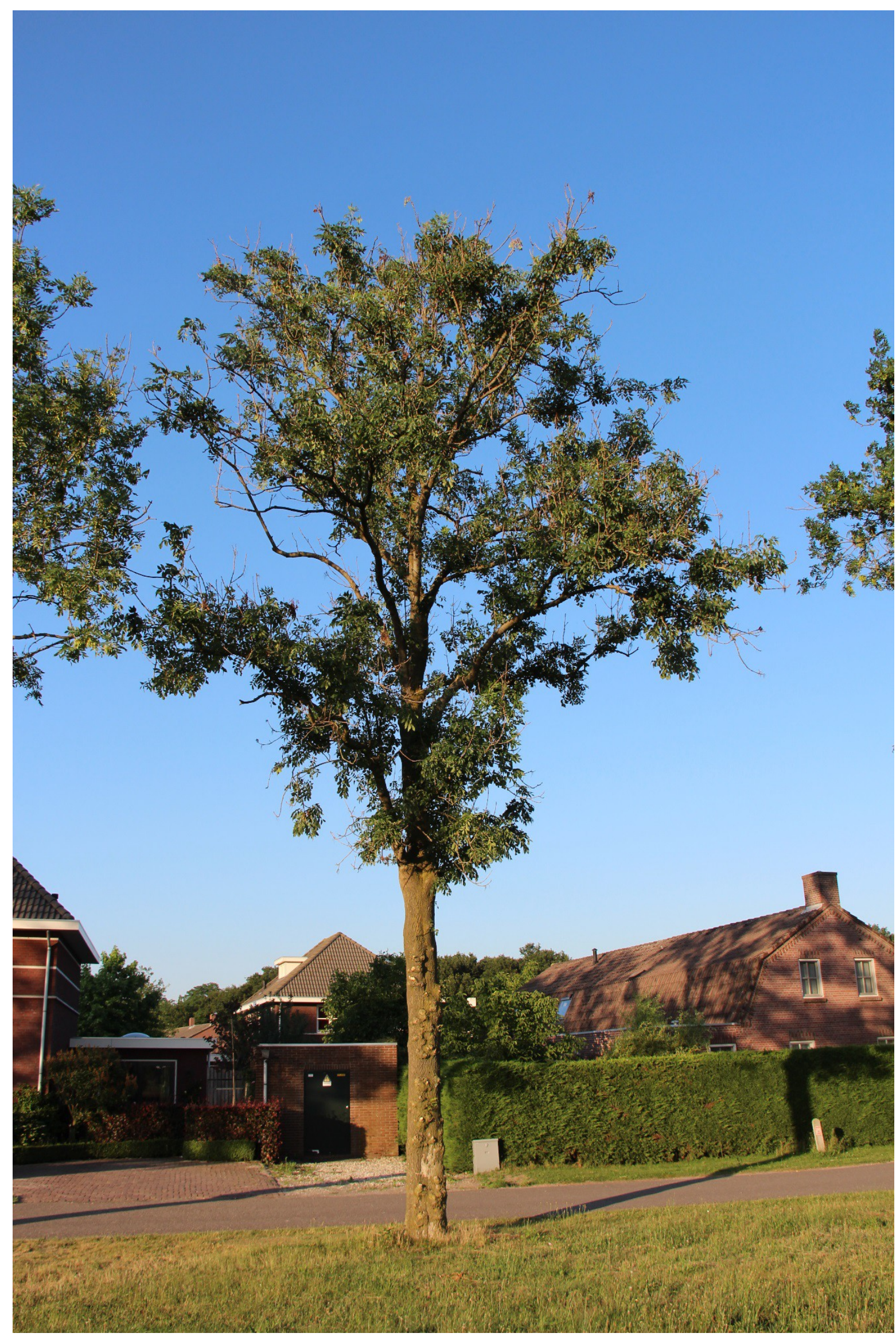

Foto 15b. Matige aantasting, ziekteklasse 2 


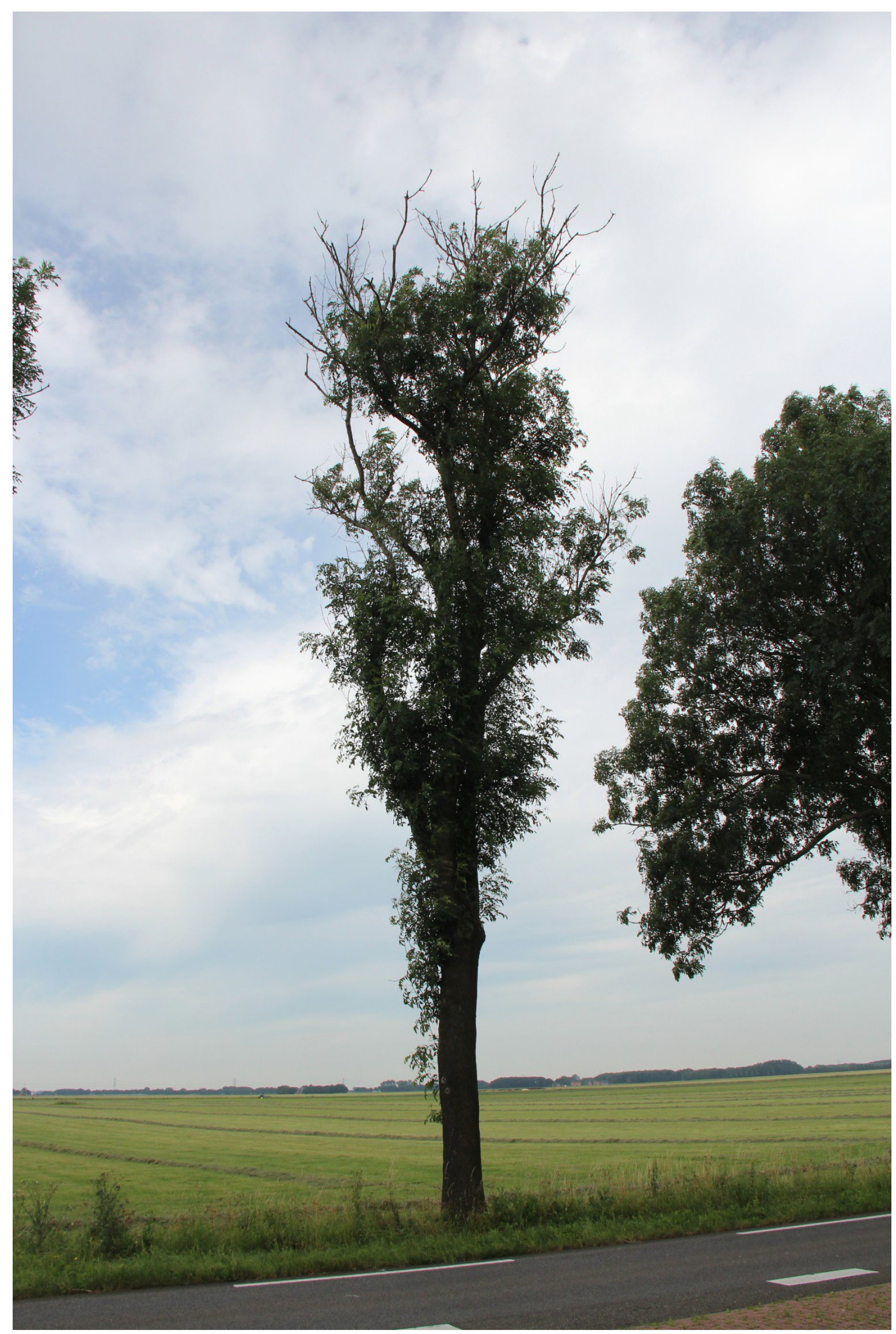

Foto 16a. Zware aantasting, ziekteklasse 3 


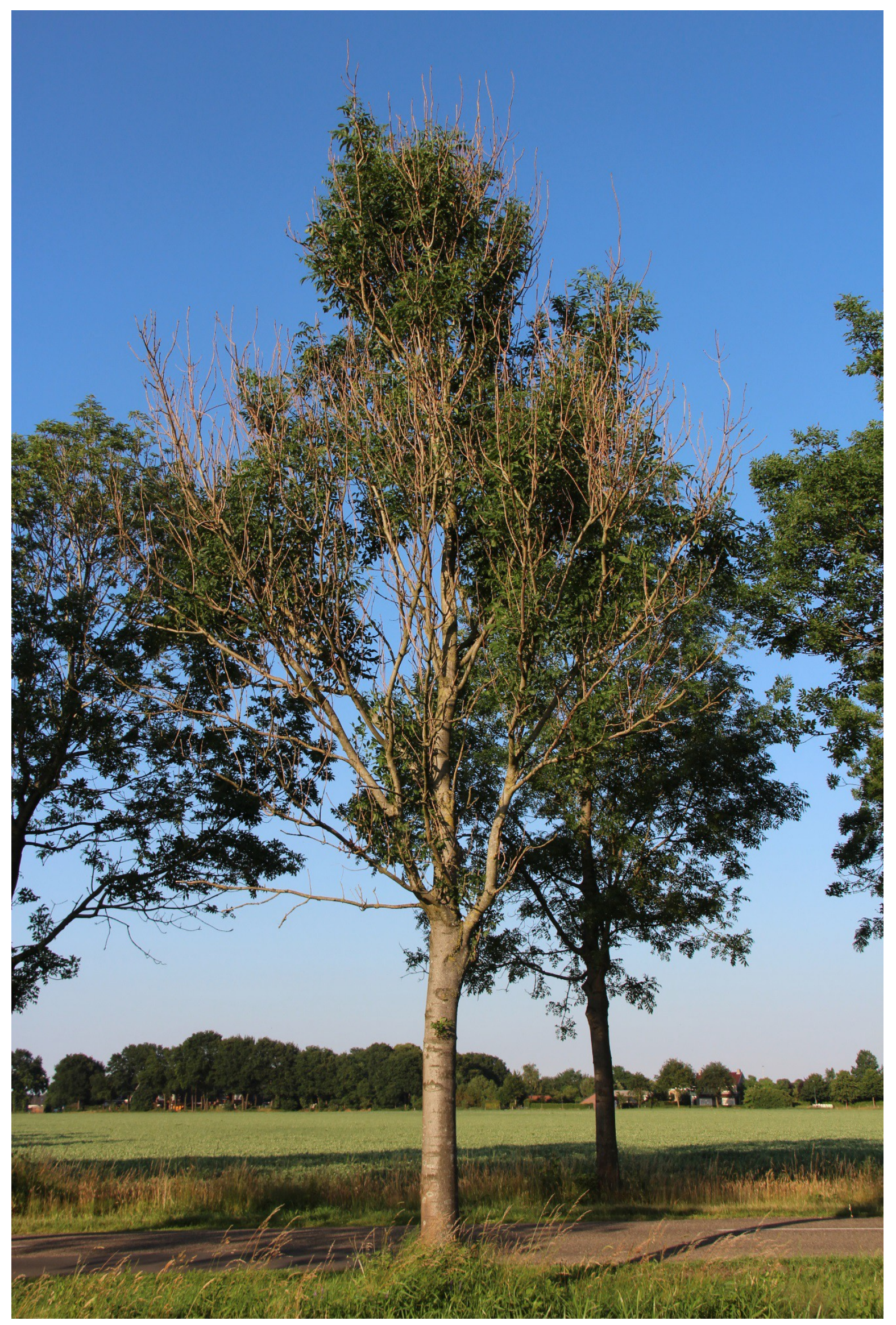

Foto $16 \mathrm{~b}$. Zware aantasting, ziekteklasse 4 


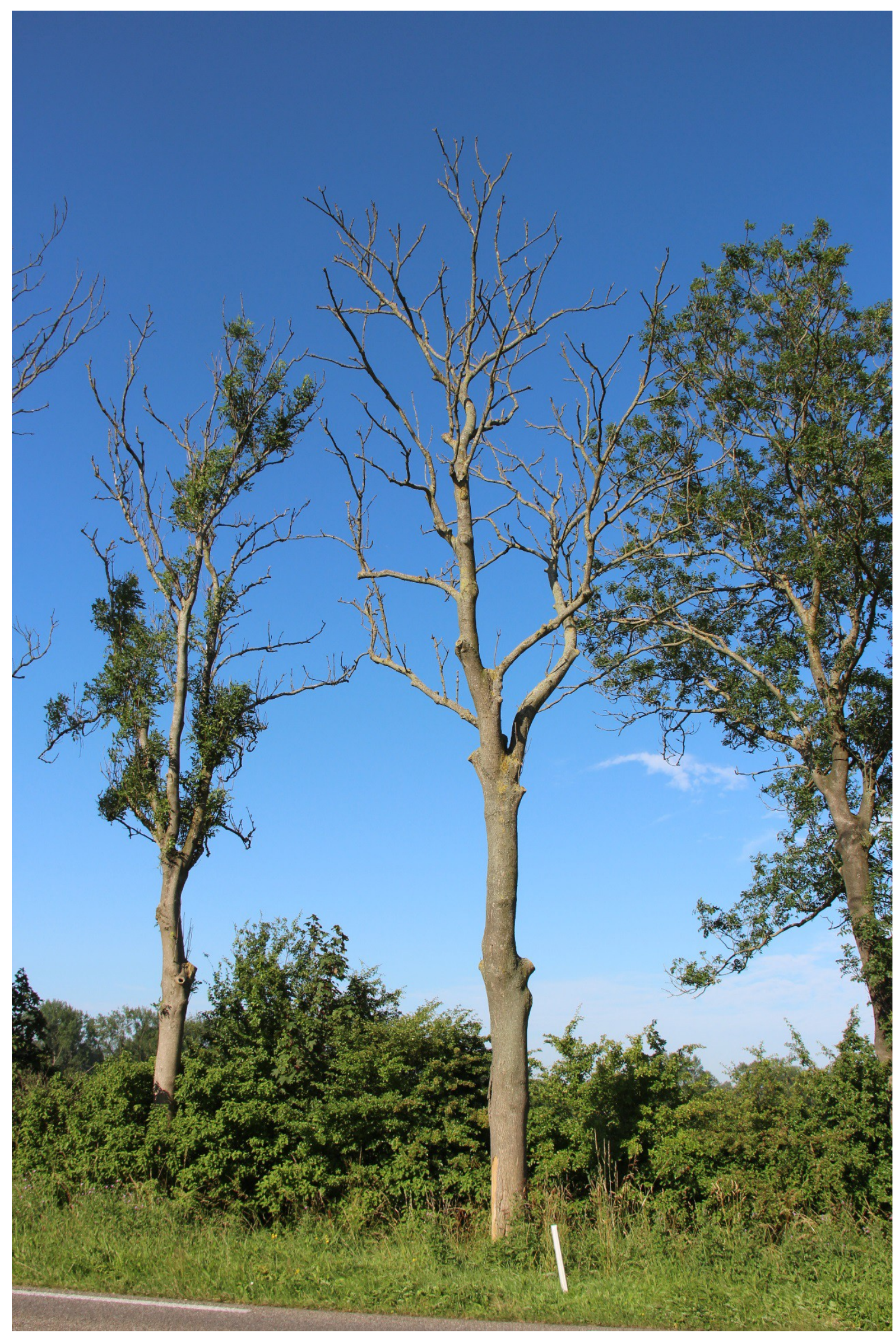

Foto 17. Dood, ziekteklasse 5 